\title{
Whose Motive Matters?: Discrimination in Multi-Actor Employment Decision Making
}

\author{
Rebecca Hanner White* \\ Linda Hamilton Krieger"*
}

\section{INTRODUCTION}

"The ultimate question in every employment discrimination case involving a claim of disparate treatment is whether the plaintiff was the victim of intentional discrimination." This statement by the Supreme Court in Reeves v. Sanderson Plumbing Products ${ }^{2}$ recites a basic and familiar principle of employment discrimination law. A successful disparate treatment claim requires a finding of an intent to discriminate.

But who must intend to discriminate? One could start with the obvious answer: a statutory employer must possess the requisite intent. Federal employment discrimination statutes, after all, hold only those who meet the statutory definitions of employer, and not the world at large, responsible for employment discrimination. ${ }^{3}$

Employers, however, particularly those with the requisite number of employees, ${ }^{4}$ usually are corporate entities who, more often than not, are held vicariously, not directly, liable for employment decisions made by supervisory employees. ${ }^{5}$ Is it, then, the individual supervisor's intent that matters in disparate treatment cases? That appears to be the accepted view; disparate treatment analysis generally proceeds from the assumption that an individual supervisor has taken a challenged action and then questions whether that supervisor acted with the requisite intent. ${ }^{6}$

Copyright 2001 , by LOUISIANA LAW REVIEW.

- J. Alton Hosch Professor of Law, University of Georgia School of Law.

** Acting Professor of Law, University of California at Berkeley School of Law (Boait Hall).

The authors would like to thank research assistants Melissa Malcom and Tara Nicole Beasley for their work.

1. Reeves v. Sanderson Plumbing Prods., Inc., 530 U.S. 133, 120 S. Ct. 2097, 2111 (2000).

2. 530 U.S. 133, 120 S. Ct. 2097 (2000).

3. See Title VIl of the Civil Rights Act of 1964, 42 U.S.C. $\$ 2000 \mathrm{e}-2$ (a)(1994); Age Discrimination in Employment Act of 1967, 29 U.S.C. $\$$ 623(1999); Americans with Disabilities Act, 42 U.S.C. $\S 12112$ (2000). The statutes also prohibit discrimination by labor organizations and employment agencies, but the focus here, as is true in the vast bulk of the reported cases, is on discrimination by employers.

4. Title VII and the Americans with Disabilities Act define employers to include those "with 15 or more employees for each working day in each of twenty or more calendar weeks in the current or preceding calendar year." 42 U.S.C. $\$ 2000$ e(b)(1994); 42 U.S.C. $\$ 12111(5)(A)(2000)$. The ADEA covers employers with 20 or more employees. 29 U.S.C. $\$ 630(b)(1999)$.

5. Vicarious liability imposes liability on an employer for the acts of its agents. See W. Page Keeton et al, Prosser and Keeton on the Law of Torts $\$ \S 69-70$, at 499-508 (5th ed. 1984). See Burlington Indus., Inc. v. Ellerth, 524 U.S. 742, 118 S. Ct. 2257 (1998) (discussing the rationale for imposing vicarious liability on employers in employment discrimination cases).

6. Martha S. West, Gender Bias in Academic Robes: The Law's Failure to Protect Women Faculty, 67 Temp. L. Q. 67, 130 (1994) (noting Supreme Court's focus on single decision makers in 
But it is not at all unusual in many employment settings for a particular employment decision to be made not by a single individual but by a number of persons. Sometimes, employment decisions are made after a recommendation works its way up the chain of authority; sometimes employment decisions are made by a committee or other ad hoc group; and sometimes the decision making process includes both. ${ }^{7}$

The facts in Reeves, for example, present a common scenario. Roger Reeves supervised a production line in Sanderson Plumbing Products's Hinge Room. ${ }^{8}$ After complaints about attendance problems in Reeves's department were made, the company's Director of Manufacturing, Powe Chestnut, ordered an audit. Following that audit, Chestnut, together with the Vice-President of Human Resources, Dana Jester, and the Vice-President of Operations, Tom Whitaker, recommended to the company's president, Sandra Sanderson, that Reeves be fired. ${ }^{10}$ Sanderson, who not only was the president of the company but Chestnut's wife, ${ }^{11}$ accepted that recommendation and fired Reeves. ${ }^{12}$ Thus, the decision making process involved in Reeves' firing involved both a recommendation that went up the chain of command (what we will refer to as vertical decision making) and a recommendation that was itself the product of group action (what we will refer to as horizontal decision-making). At least four people were involved, at one stage or the other, in the decision to terminate Reeves' employment.

Only one of those persons, Powe Chestnut, was deemed to have harbored any age-based animus. ${ }^{13}$ Yet it was not Chestnut, but company president Sanderson, who actually fired Reeves, and no evidence of any age-based motivation on her part was presented. ${ }^{14}$ Indeed, the appeals court, in finding insufficient evidence of intentional discrimination, noted that Sanderson was herself over fifty years old. ${ }^{15}$ Sanderson Plumbing Products, however, was held liable for intentional discrimination by the Supreme Court, even though the ultimate decision maker

employment discrimination cases).

7. Charles A. Sullivan, Accounting for Price Waterhouse: Proving Disparate Treatment Under Title VII, 56 Brook. L. Rev. 1107, 1138 (1991) ("In reality, many employment decisions involve multiple decisionmakers, either in a collegial or a hierarchical structure."); West, supra note 6, at 130, pointing out that faculty personnel decisions "are the result of a process where often no specific individual's intent is either discernible or can be labeled as a 'motivating factor' causing the decision to be made."

8. 530 U.S. 133, 137, 120 S. Ct. 2097, 2103 (2000).

9. Id. at $143,120 \mathrm{~S}$. Ct. at 2106.

10. Id. at $144,120 \mathrm{~S}$. Ct. at 2107.

11. Id. at $152,120 \mathrm{~S}$. Ct. at 2111 .

12. Id. at $144,120 \mathrm{~S}$. Ct. at 2107.

13. Id. at $151,120 \mathrm{~S}$. Ct. at 2110 . Chestnut was alleged to have told Reeves that he "was so old [he] must have come over on the Mayflower," and that he "was too damn old to do his [job.]" The statements, however, were not made in the context of Reeves' termination and thus were viewed as circumstantial, not direct, evidence of discrimination.

14. Nor did plaintiff allege that the two other individuals (Jester and Whitaker) involved in the recommendation that he be fired were motivated by his age. Id. at $139,120 \mathrm{~S}$. Ct. at 2104 .

15. Id. 
presumably did not mean to fire, nor understood that she was firing Roger Reeves because of his age.

Given the intent requirement, how could such a result have been reached? There are at least two possible explanations. First, one could read the Reeves Court as imposing liability because it believed that, whatever the formal structure used to arrive at the termination decision, the person who in fact made the decision to fire Reeves was Chestnut, the person with the age-based animus. Certainly there is language in the Court's opinion to that effect. The Court pointed to evidence that Chestnut wielded "absolute power" in the company and "was principally responsible for [Reeves'] firing."16 The Court even referred to Chestnut as the "actual decision maker," even though it was his wife who pulled the trigger. ${ }^{17}$

Thus, it is possible to read the Reeves opinion as insisting on evidence that the "actual decision maker" be the individual possessing the requisite intent. ${ }^{18}$ It is also possible, although more difficult, to read Reeves as holding that whenever anyone in the decision-making process has expressed discriminatory animus toward the plaintiff, that evidence will support employer liability when a prima facie case and evidence undermining the articulated reason has been presented. ${ }^{19}$ But Reeves, we believe, is best read as not confronting directly the difficult question of how to determine whether discriminatory intent is present in cases where multiple actors are involved in the decision making process. By concluding that the individual possessing unlawful animus was also the "actual decision maker," the Reeves Court was able to sidestep this difficult question.

It is a question that has intrigued each of us for some time. How should courts go about deciding whether intentional discrimination has occurred when an employment decision is the result of either a vertical and/or a horizontal decision making process? Answering this question ultimately depends on what the Court means by "intentional discrimination."

There is language in some of the Court's decisions suggesting that an intent to discriminate requires a conscious decision to act on the basis of, if not animus, at least on the basis of an "inaccurate and stigmatizing stereotype." ${ }^{20}$ But reading the

16. Id. at $151-52,120 \mathrm{~S}$. Ct. at $2110-11$

17. Id. In describing Chestnut as the "actual decisionmaker," the Court pointed to the fact that he was married to the person who made the "formal decision" to fire Reeves. The thinly veiled suggestion was that Sanderson was a mere figurehead, while her husband was essentially calling the shots.

18. The Court does refer to Chestnut in this fashion at several places in the decision. Moreover, in finding sufficient evidence to support the jury verdict in Reeves' favor, the Court coupled the statements indicating Chestnut's age-based animus with evidence that Chestnut "was principally responsible for petitioner's firing." Id. at $151,120 \mathrm{~S}$. Ct. at 2110.

19. It is difficult to assert that the Court so held because of the repeated references to evidence of Chestnut's role as the "actual decision maker." However, the Court did hold that a prima facie case, together with evidence that the proffered justification is false, may permit a fact finder to conclude that the employer unlawfully discriminated. Statements reflecting animus by anyone involved in the decision-making process, whether or not they were the "actual decision maker," would serve to strengthen a plaintiff's case.

20. Hazen Paper Co. v. Biggins, 507 U.S. 604, 610113 S. Ct. 1701, 1706 (1993). 
Court's decisions as a whole makes (or should make) abundantly clear that no animus, ill will, prejudice or inaccurate stereotype need be at work. ${ }^{21}$ Rather, a decision consciously premised on a protected characteristic is intentional discrimination, even if benign business objectives, not prejudice, drive the employer's race-based or sex-based decision. Intent, as various commentators have correctly noted, is best understood not as animus but as a causation concept, one that asks whether the plaintiff's race, sex, etc. caused the decision to occur. ${ }^{22}$

But must this use of race or sex by a decision maker be conscious for disparate treatment to exist? In other words, must the employer (or its agents) consciously intend to take the protected characteristic into account in making the employment decision at issue? Surprisingly, the Supreme Court has yet to confront this issue head on. ${ }^{23}$

As a normative matter, let us be clear. We believe that Title VII should be interpreted, and the Supreme Court's decisions can and should be read, as rejecting a requirement of conscious intent. ${ }^{24}$ Instead, the intent requirement should simply be viewed as mandating proof of causation. If an employee was treated differently by his employer because of the protected characteristic, or, to put it another way, if an employee's race or sex played a role in the employer's decision, then a disparate treatment claim should exist. ${ }^{25}$

21. See infra notes $37-48$ and accompanying text.

22. See Evan Tsen Lee \& Ashutosh Bhagwat, The McClesky Puzzle: Remedying Prosecutorial Discrimination Against Black Victims in Capital Sentencing, 1998 Sup. Ct. Rev. 145; Mary Ellen Maatman, Choosing Words and Creating Worlds: The Supreme Court's Rhetoric and Its Constitutive Effects on Employment Discrimination Law, 60 U. Pitt. L. Rev. 1 (1998); Ann C. McGinley, IViva La Evolucion! Recognizing Unconscious Motive in Title VII, 9 Cornell J. Law \& Pub. Pol., 415 (2000); Michael Selmi, Proving Intentional Discrimination: The Reality of Supreme Court Rhetoric, 86 Geo. L. J. 279 (1997); Linda Hamilton Krieger, The Content of Our Categories: A Cognitive Bias Approach to Discrimination and Equal Opportunity, 47 Stan. L. Rev. 1161, 1242-43 (1995); Larry G. Simon, Racially Prejudicial Governmental Actions: A Motivation Theory of the Constitutional Ban Against Racial Discrimination, 15 San Diego L. Rev. 1041, 1065 (1978); David A. Strauss, Discriminatory Intent and the Taming of Brown, 56 U. Chi. L. Rev. 935 (1989); D. Don Welch, Removing Discriminatory Barriers: Basing Disparate Treatment Analysis on Motive Rather Than Intent, $60 \mathrm{~S}$. Cal. L.Rev. 733 (1987).

23. Lee \& Bhagwat, supra note 22 , at 154 (Court "has never squarely considered the possibility" that race may have caused a decision to occur without the governmental actor's conscious awareness that it took race into account.).

24. Others hold a similar view. Lee \& Bhagwat, supra note 22 (reaching similar conclusion in equal protection context); McGinley, supra note 22; Selmi, supra note 22, at 288; Michael Selmi, Discrimination as Accident: Old Whine, New Bottle, 74 Ind. L. J. 1233 (1999); Strauss, supra note 22; Welch, supra note 22. But see Charles R. Lawrence III, The Id, the Ego, and Equal Protection: Reckoning with Unconscious Racism, 39 Stan. L. Rev. 317, 324 (1987) (advocating a cultural meaning approach to equal protection adjudications and observing that equal protection cases presently require proof that defendant was consciously aware of his animus or consciously intended to discriminate); Amy L. Wax, Discrimination as Accident, 74 Ind. L. J. 1129 (1999) (acknowledging Court's decisions may be construed to permit recovery for "unconscious discrimination" but contending that employers should not be held liable for unconscious discrimination by their agents).

25. Krieger, supra note 22 at $1242-43$ (advocating a causation-based approach and arguing that it could be implemented without amending Title VII). Various other commentators claiming that intent is a causation driven inquiry have argued that "unconscious" discrimination is presently actionable. 
But to articulate how the Court's disparate treatment decisions should be interpreted is not to say that this is how lower courts are in fact interpreting or applying them. It is the unusual case, to say the least, in which a supervisor's unconscious bias has resulted in disparate treatment liability. ${ }^{26}$ Indeed, in examining whether disparate treatment has occurred, lower courts continue to search for conscious intent. ${ }^{27}$

Framing the disparate treatment inquiry as a search for conscious intent, however, under-identifies instances in which an employee or applicant has been denied employment opportunity because of his or her protected group status. People are often not consciously aware of what in fact moves them to act. ${ }^{28}$ Accordingly, race, sex or age may have played a role in a decision without the decision maker's active awareness that it was doing so. Rather than search for evidence of a consciously held bias or motive, as too often occurs, a court should focus the factual inquiry in a disparate treatment case on the question of causation. All the facts and circumstances should be examined to determine whether the protected characteristic played a causal role in the decision. In sum, the disparate treatment inquiry should focus on causation, not conscious discrimination. ${ }^{29}$

Importantly, we find that thinking about discriminatory motivation in multiple actor situations demonstrates why this must be so. In the vertical decision making context, the question must not be whether the "actual decision maker" harbored discriminatory animus, or even a conscious awareness that race, sex, etc. was motivating the decision. The application of such a rule would require a finding against the plaintiff in too many contexts in which even conscious, deliberate discrimination by an agent of the employer, acting within the course and scope of his employment, had caused the challenged action to be taken. Instead, as we will show, and as various lower courts have recognized, the question should be whether there exists an unbroken chain of causation between the employee's race and the challenged decision. ${ }^{30}$

With respect to horizontal decision making, where a decision emerges from a group process, it makes little sense to search for a consciously held "collective intent," except perhaps as a metaphor for some more complex set of phenomena." Groups do not "think," only individual people do. But an individual's membership

See Lee \& Bhagwat, supra note 22; McGinley, supra note 22; Selmi, supra note 22; Strauss, supra note 22; Welch, supra note 22 . Whether the protected characteristic need be the "but-for" cause or need only have played a motivating role depends upon the statutory claim at issue. See infra notes 63-68 and accompanying text.

26. See infra notes $77-79$ and accompanying text.

27. See infra notes 69.85 and accompanying text.

28. A substantial body of empirical evidence supporting this claim is described in Krieger, supra note 22 , at 1213-16.

29. See sources cited supra notes 22-24.

30. See infra notes 97-136 and accompanying text.

31. See Lee \& Bhagwat, supra note 22, at 154. "The argument in favor of a purely causation based approach to intent, powerful as it is when applied to individual governmental decisionmakers, becomes overwhelming when the government conduct at issue is the product of collective decisionmaking, as many discriminatory state policies are."). 
in a group may shape his or her judgment in ways quite significant to a discrimination inquiry. ${ }^{32}$ Exploring the various ways in which discrimination can occur when multiple agents play a role in the decision making process, and examining the parallels between group and individual decision making, helps clarify that the question of intent in employment discrimination cases must, at bottom, be approached as a question of causation

Causation alone, however, is not enough. The action in which an employee's race, sex, or other protected characteristic played a causal role must be attributable to the employer. Vicarious liability principles determine when actions caused, at least in part, by an employee's race, sex or other protected characteristic may be attributed to an employer, and these principles must be applied in determining when a disparate treatment claim involving multiple decision makers is actionable. Importantly, consideration of vicarious liability theory helps refute arguments that a causation-based approach to employment discrimination is an over-inclusive method for remedying employment discrimination.

\section{Disparate TREATMENT Claims: ThE INTENT REQUiREMENT}

Disparate treatment, the Supreme Court tells us, is the "most easily understood type of discrimination. The employer simply treats some people less favorably than others because of their race, color, religion, sex or national origin. Proof of discriminatory motive is critical, although it can in some situations be inferred from the mere fact of differences in treatment." ${ }^{33}$ The existence of this discriminatory motive is what distinguishes a disparate treatment claim from one involving disparate impact, in which proof of a discriminatory motive is unnecessary. ${ }^{34}$ In describing disparate treatment claims, the Court uses the terms discriminatory intent and discriminatory motive interchangeably, as will we. ${ }^{35}$ In fact, however, motive is the more accurate term, as it focuses on the reason for an act or why an act is occurring, not on whether the employer intends to perform the act. ${ }^{36}$ Sanderson Plumbing Products intended to fire Roger Reeves; on that point, there was no dispute. Instead, the question was why the termination had occurred.

32. See infra notes 221-28 and accompanying text.

33. International Brotherhood of Teamsters v. United States, 431 U.S. 324, 335 n.15 97 S. Ct. 1843, 1854-55 n.15 (1977).

34. Id. at 335-36,97 S. Ct. at 1854-55 n.15 ("Claims of disparate treatment may be distinguished from claims that stress 'disparate impact.' The latter involve employment practices that are facially neutral in their treatment of different groups but that in fact fall more harshly on one group than another and cannot be justified by business necessity. Proof of discriminatory motive, we have held, is not required under a disparate-impact theory.").

35. The Court's habit of equating the terms occurred in cases arising under the National Labor Relations Act and has continued under Title VII and the ADEA. Since the Court uses the terms interchangeably, commentators have as well. See Thomas G.S. Christensen \& Andrea H. Svanoe, Motive and Intent in the Commission of Unfair Labor Practices: The Supreme Court and the Fictive Formality, 77 Yale L. J. 1269 (1968); Welch, supra note 22, at 763-64.

36. See Mark C. Weber, Beyond Price Waterhouse v. Hopkins: A New Approach to Mixed Motive Discrimination, 68 N.C. L. Rev. 495, 498 (1990); Welch, supra note 22, at 738. 


\section{A. The Question of Hostile Animus}

For years, it has (or should have) been clear that discriminatory intent or motive is not coextensive with hostile animus. ${ }^{37}$ While an employer's hostility, hatred or ill will toward plaintiff's race, sex, etc. will provide powerful evidence that the protected factor motivated the employer's decision, such hostility, hatred or ill will is not a required element of a disparate treatment claim. Instead, what must be shown is that a plaintiff's race, sex, etc. motivated the decision, even if the employer lacked any ill will.

For example, in Los Angeles Department of Water \& Power v. Manhart, ${ }^{38}$ the Supreme Court struck down a policy requiring women to make larger pension contributions than men because women as a group live longer than men as a group. The policy was facially discriminatory because "it does not pass the simple test of whether the evidence shows treatment of a person in a manner which but for that person's sex would be different." 39 That the difference in treatment was based on legitimate cost concerns, not hostile animus toward women, did not relieve the employer of liability.

More recently, in International Union, UAWv. Johnson Controls, the Court confirmed that an intentional difference in treatment because of sex is all that is needed for a disparate treatment claim. ${ }^{40}$ The Court rejected the employer's argument that no disparate treatment claim should exist because it had excluded women from numerous factory positions not out of animus but out of a concern for fetal health." As the Court stated, "Johnson Controls's policy is not neutral because it does not apply to the reproductive capacity of the company's male employees in the same way as it applies to that of the females. Moreover, the absence of a malevolent motive does not convert a facially discriminatory policy into a neutral policy." ${ }^{12}$ The proper inquiry thus is not why the employer is treating women differently from men but whether it is treating women differently than men.

In recent years, and despite the Court's holdings in Manhart and Johnson Controls, the equation of discriminatory intent with hostile animus still powerfully shapes the decisions of many lower courts. ${ }^{43}$ For example, the district court in

37. See Strauss, supra note 22, at 962-65.

38. 435 U.S. 702,98 S. Ct. 1370 (1978).

39. Id. at $711,98 \mathrm{~S}$. Ct. 1377

40. 499 U.S. 187,111 S. Ct. 1196 (1991).

41. Id. at $199,111 \mathrm{~S}$. Ct. at 1203-04. This argument had been accepted by three circuits, despite the facially discriminatory nature of fetal protection policies. See International Union, UAW v. Johnson Controls, 886 F.2d 871 (7th Cir. 1989), rev'd, 499 U.S. 187, 111 S. Ct. 1198 (1991); Hayes v. Shelby Mem'l Hosp., 726 F.2d 1543 (11 th Cir. 1984); Wright v. Olin Corp., 697 F.2d 1172 (4th Cir. 1982).

42. 499 U.S. at 199, 111 S. Ct. at 1203-04. See also Phillips v. Martin Marietta Corp., 400 U.S. 542, 544, 91 S. Ct. 496 (1971) (employer's refusal to hire women with young children unlawful, even though no hostility or animus toward women existed).

43. See McGinley, supra note 22, at 480 (noting escalation of this trend). See also Linda Hamilton Krieger, Civil Rights Perestroika: Intergroup Bias After Affirmative Action, 86 Cal. L. Rev. 1251,1311 (1998) (noting tendency to view discrimination as stemming from hostile animus). 
EEOC v. Joe's Stone Crab found no disparate treatment despite considerable evidence that the restaurant had followed the "European" tradition of equating "'fine dining ambience' with male food service." Although this aspect of the decision was criticized on appeal, with the Eleventh Circuit advising the trial court that a finding of intentional discrimination does not require group animus, ill will or malice toward women, ${ }^{45}$ that such clarification should be needed in 2000 , thirtyfive years after Title VII's adoption, is cause for concern.

The 1991 amendments to Title VII underscore that hostile animus is not needed for a disparate treatment claim. The statute was amended to clarify that "a demonstration that an employment practice is required by business necessity may not be used as a defense against a claim of intentional discrimination." ${ }^{146}$ While a decision maker's animus may be powerful evidence of intentional discrimination, ${ }^{47}$ the absence of animus does not mean that intentional discrimination has not occurred. When an employer has taken protected group status into account in making an employment decision, intentional discrimination has occurred. ${ }^{48}$

\section{B. Intent as Causation}

At the same time, the Supreme Court also has made clear that an awareness that a decision will adversely affect a protected group is not the functional equivalent of an intent to discriminate. For intentional discrimination to exist, the employer must act because of the protected characteristic, not in spite of it. ${ }^{49}$ Thus, in Personnel Adminstrator v. Feeney, the Court rejected an equal protection attack on a veterans' preference law. ${ }^{50}$ Although the law overwhelmingly advantaged men,

44. EEOC v. Joe's Stone Crab, Inc., 969 F. Supp. 727, 731-33 (S.D. Fla. 1997), vacated and remanded, 220 F.3d 1263 (11 th Cir. 2000).

45. 220 F.3d at 1283-84 n.19 ("[W]e believe the district court's conclusion that the EEOC has not met its burden of proving intentional discrimination may have been based on an erroneous view of Title VII case law .... We emphasize that a finding of disparate treatment requires no more than a finding that women were intentionally treated differently by Joe's because of or on account of their gender. To prove the discriminatory intent necessary for a disparate treatment or pattern or practice claim, a plaintiff need not prove that a defendant harbored some special 'animus' or 'malice' towards the protected group to which she belongs.... Several ambiguous phrases in the district court's opinion suggest that the district court may have been operating under this erroneous view.").

46. 42 U.S.C. $\$ 2000 \mathrm{e}-2(\mathrm{k})(2)(1994)$.

47. See Reeves v. Sanderson Plumbing Prods., 530 U.S. 133, 120 S. Ct. 2097, 2110 (2000).

48. Not all intentional discrimination by an employer, however, is unlawful. An employer that intentionally discriminates may avoid liability if it can establish that sex, national origin, or religion is a bona fide occupational qualification for the job at issue. There is no BFOQ for race. See 42 U.S.C. $\$ 2000 \mathrm{e}-2(\mathrm{e})(1)(1994)$. The BFOQ affirmative defense is extremely narrow. See International Union v. Johnson Controls, Inc., 499 U.S. 187, 202-04, 111 S. Ct. 1196, 1205-06 (1991) (rejecting BFOQ defense in fetal protection case). Additionally, an employer may take race or sex into account in making employment decisions when it does so under a lawful affirmative action plan. Such a use of race or sex is not considered unlawful discrimination within the meaning of Title VII. Johnson $v$. Transportation Agency of Santa Clara County, 480 U.S. 616, 107 S. Ct. 1442 (1987).

49. Personnel Administrator v. Feeney, 442 U.S. 256, 278-79, 99 S. Ct. 2282, 2304-05 (1979).

50. Id. See Selmi, supra note 22 , at 292 , who reads Feeny as adopting causation as the standard for intent; Lee \& Bhagwat, supra note 22, at 152 (same). 
the Court found the Massachusetts legislature had not enacted or maintained the law for the purpose of disadvantaging women but in spite of that adverse impact on them. "Discriminatory purpose," the Court held, "implies more than intent as volition or intent as awareness of consequences. It implies that the decisionmaker ... selected or reaffirmed a particular course of action at least in part 'because of,' not merely "in spite of its adverse effects upon an identifiable group." "51 Although Feeney was a constitutional, not statutory, decision, the judicial approach to intentional discrimination in Fourteenth Amendment claims and its approach to intentional discrimination under Title VII has been consistent. ${ }^{\mathbf{5 2}}$

Feeney's invocation of the "because of" test corresponds to the statutory language used in Title VII, the ADEA and the ADA. Each makes it prima facie unlawful for an employer to take an employment action "because of" the protected characteristic. $^{53}$ Accordingly, the Supreme Court's disparate treatment decisions, properly construed; would view the motive or intent inquiry not as a search for hostile animus or for adverse effects but as a search for causation. ${ }^{54}$ Discrimination is "because of" race, sex, age, etc. when the protected characteristic caused, in whole or in part, the decision to occur.

The Court's various opinions in Price Waterhouse v. Hopkins support this view. ${ }^{55}$ Interestingly, each of the opinions in Price Waterhouse viewed the question of unlawful motive as a causation inquiry. Indeed, the Price Waterhouse plurality

51. 442 U.S. at $279,99 \mathrm{~S}$. Ct. at 2305 . While the obvious impact of an action on a protected group may be powerful evidence that the defendant acted to achieve that impact, the impact is merely evidence of unlawful motive, not the functional equivalent of it.

52. There are significant differences in the procedural aspects of such claims, but the substantive aspects of purposeful discrimination appear to be the same. St. Mary's Honor Center v. Hicks, 509 U.S. S02, 113 S. Ct. 2742 (1993). See Harold S. Lewis, Jr., Civil Rights and Employment Discrimination Law 342-43 (1997) (noting courts have considered that purposeful discrimination under equal protection clause and Title VII to be equivalent and collecting cases). The Court, however, has rejected the use of disparate impact theory under the equal protection clause. Washington v. Davis, 426 U.S. 229, S. Ct. 2040 (1976).

53. 42 U.S.C. $\$ 2000 \mathrm{e}-2(a)(1)(2000)$ ("It shall be an unlawful employment practice for an employer ... to fail or refuse to hire or to discharge any individual, or otherwise to discriminate against any individual with respect to his compensation, terms, conditions or privileges of employment, because of such individual's race, color, religion, sex, or national origin"); 42 U.S.C. $\$ 12112(2000)$ ('No covered entity shall discriminate against a qualified individual with a disability because of the disability of such individual . ..."); 29 U.S.C. $\$ 623$ (a)(1) (1998) ("It shall be an unlawful employment practice for an employer ... to fail or refuse to hire or to discharge any individual or otherwise to discriminate against any individual with respect to his compensation, terms, conditions or privileges of employment because of such individual's age.").

54. See sources cited supra note 22. As recently noted by Professor McGinley, the intent element in employment discrimination cases is not a state of mind element as in tort law but instead "plays the same role as but-for causation." McGinley, supra note 22, at 477-79. See also Rebecca Hanner White, Modern Discrimination Theory and the National Labor Relations Act, 39 Wm. \& Mary L. Rev. 99, 140-44 (1997) (contrasting the causation based approach to intent under Title VII with the animus based approach to intent under the NLRA).

55. 490 U.S. 228,109 S. Ct. 1775 (1989). Although agreeing that Price Waterhouse made clear that intent is causation driven, Professor Maatman criticizes the Court for failing to define what "because of" means. Maatman, supra note 22, at 2. 
and the dissent disagreed not over whether but-for causation was the critical question, but rather, over which party bore the burden of proving it. The plurality, joined by Justices White and $O$ 'Connor, believed that once the plaintiff proved that her sex was a motivating factor (Justices White and O'Connor would say substantial motivating factor) in the challenged decision, she would be entitled to a verdict in her favor, unless her employer could prove that it would have made the same decision anyway. ${ }^{56}$ This approach essentially shifted to the defendant the burden of proving that sex was not the but-for cause of its decision. ${ }^{57}$ The dissent would have required the plaintiff to prove not only that sex was a motivating factor, but also that it was the but-for cause of the challenged decision. ${ }^{58}$

Similarly, in St. Mary's Honor Center v. Hicks, the Court, while rejecting the notion that an employee who proves the nondiscriminatory reason proffered by his employer is pretextual is entitled to judgment as a matter of law, confirmed that the real question in disparate treatment cases is whether the decision was made because of the plaintiff's race..$^{99}$ And in McKennon v. Nashville Banner Publishing Co. ${ }^{60}$ the Court refused to permit employers to avoid liability on the basis of evidence of wrongdoing discovered after the employment decision was made. The focus, McKennon confirmed, is on the time the decision is made. ${ }^{61}$ Reasons unknown to the employer at the time it acted could not have caused the act to occur and thus could not eliminate liability. Most recently, in permitting same-sex sexual harassment cases to proceed, the Court's decision in Oncale v. Sundowner Offshore Services reaffirmed that the key issue in a sexual harassment case-or for that matter, any other sex discrimination case-is whether the plaintiff has been victimized because of his or her sex..$^{62}$

Suggesting that the intent requirement should be understood as an inquiry into causation is hardly a novel idea. Legal scholars have for some time argued that intent to discriminate should be understood in this way. ${ }^{63}$ The degree of causation required by employment discrimination statutes, however, is very much in dispute, particularly after the 1991 Civil Rights Act's amendment to Title VII in response to Price Waterhouse. Section $703(\mathrm{~m})$ provides that "an unlawful employment

56. 490 U.S. at $244-45,259,262,109$ S. Ct. at 1791-92, 1806.

57. Although the plurality did not read the terms "because of" as requiring a showing of "but-for" causation, but only that the protected characteristic be a motivating factor in the employment decision, it did permit an employer to avoid liability by establishing it would have reached the same decision even if it had not taken the protected characteristic into account. Id. at $240-41,109 \mathrm{~S}$. Ct. at 1797 . This effectively endorsed a but-for test of liability, as Justice Kennedy's dissent correctly noted. Id. at 281, 109 S. Ct. at 1828 (Kennedy, J., dissenting). See Sullivan, supra note 7, at 1.126 n.67.

58. Id. at 287,109 S. Ct. at 1834 (Kennedy, J. dissenting).

59. 509 U.S. 502, 113 S. Ct. 2742 (1993).

60. 513 U.S. 352,115 S. Ct. 879 (1995).

61. Id. at $359-60,115 \mathrm{~S}$. Ct. at 886 .

62. 523 U.S. 75,118 S. Ct. 998 (1998).

63. See Paul A. Brest, Palmer v. Thompson: An Approach to the Problem of Unconstitutional Motivation, 1971 Sup. Ct. Rev. 95, 115-24; Paul J. Gudel, Beyond Causation; The Interpretation of Action and the Mixed Motives Problem in Employment Discrimination Law, 70 Tex. L. Rev. 17 (1991); Krieger, supra note 22, at 1242; Selmi, supra note 22, at 288-91. 
practice is established when the complaining party demonstrates that race, color, religion, sex, or national origin was a motivating factor for any employment practice, even though other factors also motivated the practice."64 Professor Michael Zimmer asserts, we think convincingly, that this amendment removes "butfor" causation as an element of liability under Title VII, instead now requiring only that race, sex, etc. be "a motivating factor." 65 Causation is still required, but the protected factor need not be the "but-for" cause of the challenged decision. ${ }^{66}$ Some courts disagree, insisting that only in cases of "direct evidence" will Section 703(m) apply, thus requiring the plaintiff to prove but-for causation in circumstantial evidence cases. ${ }^{67}$ Moreover, the degree of causation required under other employment statutes, such as the ADEA and Section 1981, and even under Title VII's anti-retaliation provision, is uncertain. ${ }^{68}$ We need not engage this dispute further here, but it is relevant to point out that the very existence of the debate suggests that the motive inquiry in disparate treatment cases is, at base, a question of causation, whatever quantum of causation is deemed necessary.

64. 42 U.S.C. $\$ 2000 \mathrm{e}-2(\mathrm{~m})(2000)$.

65. Michael J. Zimmer, The Emerging Uniform Structure of Disparate Treatment Litigation, 30 Ga. L. Rev. 563, 600-09 (1996).

66. See Curley v. St. John's Univ., 19 F. Supp.2d 181, 189 (S.D.N.Y. 1998). Left to be determined in cases in which Section $703(\mathrm{~m})$ applies is what is meant by "a motivating factor." See Gudel, supra note 63, at 39 (referring to a "motivating factor" as a "shadowy concept that lies somewhere between 'but-for' and 'mere presence of a biased attitude."). Will the protected characteristic be a "motivating factor" only if it is a sufficient reason for a decision? Professor Michael Wells advocates such a test for free speech cases in lieu of a "but-for" causation model. See Michael Wells, Three Arguments Against Mt. Healthy: Tort Theory, Constitutional Torts, and Freedom of Speech, 51 Mercer L. Rev. 583, 588-89 (2000). It has been contended that the legislative history and the wording of Section 703(m) suggests the causal threshhold for a "motivating factor" is "extremely low," with liability present whenever a nexus between the discrimination and a final employment decision exists. Heather K. Gerken, Note, Understanding Mixed Motives Claims Under the Civil Rights Act of 1991: An Analysis of Intentional Discrimination Claims Based on Sex-Stereotyped Interview Questions, 91 Mich. L. Rev. 1824 (1993).

67. See, e.g., Fuller v. Phipps, 67 F.3d 1137 (4th Cir. 1995); Robert Belton, Mixed Motive Cases in Employment Discrimination Law Revisited: A Brief Updated View of the Swamp. 51 Mercer L. Rev. 651, 661-62 (2000) (describing conflict in the courts over whether Section 703(m) applies only in direct evidence cases). This approach requires resolving the complicated issue of what constitutes "direct" evidence. As Professor Belton notes, "[a]lthough the courts generally agree that plaintiffs must introduce direct evidence of a 'motivating factor' under Section 703(m), they have about as many definitions of 'direct evidence' as they do employment discrimination cases." Id. at 662 . For an interesting approach to the question of what is "direct evidence," see Wright v. Southland, 187 F.3d 1287 (11 th Cir. 1999) (J. Tjoflat).

68. Section 703(m) amends only Section 703 of Title VII and not Section 704, in which the antiretaliation provision is located. Thus, it has been held inapplicable to claims under Section 704. See McNutt v. Board of Trustees of Univ. of Illinois, 141 F.3d 706 (7th Cir. 1998); Woodson v. Scott Paper Co., 109 F.3d 913 (3d Cir. 1997); Tanca v. Nordberg, 98 F.3d 680 (1st Cir. 1996). The ADEA and Section 1981 were not amended in response to Price Waterhouse, and courts have continued to apply Price Waterhouse to mixed motive cases arising under those statutes. See, e.g., Lewis v. YMCA, 208 F.3d 1303 (11th Cir. 2000); Harris v. Shelby County.Bd. of Educ., 99 F.3d 1078 (11 th Cir. 1996). But see Curley v. St. John's Univ., 19 F. Supp.2d 181 (S.D.N.Y. 1998) (applying Section 703(m) to an ADEA claim). 


\section{Unconscious Intent}

Less certain, however, is whether to satisfy the intent requirement, the decision maker must be consciously aware that he is making a decision, at least in part, because of the plaintiff's group status. ${ }^{69}$ Unconscious intent seems oxymoronic. Numerous lower courts equate intentional discrimination with a conscious decision to take action based on a target person's or persons' membership in a particular social group. ${ }^{70}$ Moreover, various commenters, while disagreeing with the proposition that the Constitution or civil rights statutes such as Title VII should be interpreted as requiring proof of conscious intent to discriminate, suggest that this is, in fact, how such laws are generally construed in federal civil rights cases. ${ }^{71}$

Indeed, there is language in some Supreme Court opinions that supports this view. For example, in her plurality opinion in Watson v. Fort Worth Bank \& Trust, Justice $O ' C o n n o r$ described disparate treatment claims as involving the application of a "deliberately discriminatory motive" and appeared to view the "problem of subconscious stereotypes and prejudices" as outside the reach of disparate treatment claims. ${ }^{72}$ In Hazen Paper Co. v. Biggins, Justice O'Connor, this time in an opinion for the Court, described disparate treatment in terms that could be interpreted as requiring that some form of prejudice must be consciously operating. "I3 "It is the very essence of age discrimination for an older employee to be fired because the

69. As Professors Lee and Bhagwat explain, although the Court's decision in Personnel Administrator $v$. Feeney establishes that a conscious awareness of harm is not the equivalent of intent, "Feeney does not exclude the possibility that conscious awareness may be a necessary element of intent." Lee \& Bhagwat, supra note 22, at 152.

70. See infra discussion in text accompanying notes 77-79.

71. See e.g., Lawrence, supra note 24, at 304 (observing that disparate treatment doctrine requires proof of conscious awareness of animus); West, supra note 6, at 70 (noting that "only conscious and demonstrable bias is subject to legal sanction"); Krieger, supra note 22 (describing and criticizing courts' interpretation of Title VII as requiring proof of conscious intent to discriminate); McGinley, supra note 22, at 480 (observing that courts are focusing on whether a conscious and often invidious motive was present, despite psychological research demonstrating that intergroup bias is often unconscious).

72. 487 U.S. $977,990,108$ S. Ct. 2777, 2790 (1988) (O'Connor J., concurring) ("[E]ven if one assumed that any such discrimination can be adequately policed through disparate treatment analysis, the problem of subconscious stereotypes and prejudices would remain."). Some lower courts have used this language to support their conclusion that subconscious forms of bias, if they are to be remedied at all, must be addressed through the application of disparate impact theory, not disparate treatment theory. See, e.g., Sperling v. Hoffman-LaRoche, 924 F. Supp. 1346, 1361-62 (D.N.J. 1996) (stating that "unlike disparate treatment analysis . . . disparate impact analysis addresses the effects of unconscious discrimination in addition to conscious or intentional discrimination."); See also Jackson v. Harvard Univ., 721 F. Supp. 1397, 1433 (D. Mass. 1989) (stating that disparate treatment analysis was never designed to police "subconscious stereotypes and prejudices").

73. 507 U.S. 604, 113 S. Ct. 1701 (1993). See Maatman, supra note 22, at 33, who reads Biggins as confining the Court's "vision of discrimination to actions consciously based on inaccurate beliefs about the employee's race, sex, religion, color, national origin, or age." She criticizes the Court's "blame-based rhetoric" as excluding "unconsciously stigmatizing beliefs" from liability. Id. at 63 . 
employer believes that productivity and competence decline with age," she stated. Reliance by employers on "inaccurate and denigrating generalizations about age," said the Court, was what Congress intended to prevent. ${ }^{74}$ Even the plurality's decision in Price Waterhouse described the motive inquiry in the following terms:

In saying that gender played a motivating part in an employment decision, we mean that, if we asked the employer at the moment of the decision what its reasons were and if we received a truthful response, one of those reasons would be that the applicant or employee was a woman. ${ }^{75}$

That statement appears to suppose an awareness on the employer's part that it is taking sex into account in its decision-making process. ${ }^{76}$

Indeed, there exist surprisingly few published Title VII disparate treatment decisions in which, after acknowledging the existence of unconscious bias, a court has ruled in favor of the plaintiff or reversed a trial court ruling for the defendant on that basis. ${ }^{77}$ This situation persists, even following the Supreme Court's decision in Price Waterhouse, ${ }^{78}$ and is accompanied by a slow but discernable accretion of

74. Maatman, supra note 22 , at 30 . However the Biggins opinion also described the intent inquiry in terms that were overtly causation based. See infra notes 81-82 and accompanying text.

75. 490 U.S. 228, 250, 109 S. Ct. 1775, 1797 (1989). As Professor Gudel notes, this definition "assumes that the sine qua non of Title VII liabilitiy is a conscious intent to discriminate." Gudel, supra note 63 , at 62 .

76. See Krieger, supra note 22 (suggesting that this language from Price Waterhouse reflects and reinforces a fallacious notion that employment decision makers have ready access to the reasons why they have made, or are about to make, a particular decision); But see McGinley, supra note 22, at 475 (asserting that the Price Waterhouse plurality "unwittingly expands the definition of intent to include the use of unconsciously or consciously held stereotypes to make employment decisions.").

77. To our knowledge, there exists only one Title VIl race discrimination case holding to this effect. Equal Employment Opportunity Comm'n v. Inland Marine, 729 F.2d 1229, 1236 (9th Cir. 1984) (holding that disparate treatment discrimination occurs where decision maker applies subjective employment criteria embodying racially discriminatory attitudes, even absent a conscious intent to discriminate), cert. denied sub nom. Inland Marine Indus. v. Houston, 469 U.S. 855, 105 S. Ct. 180 (1984). One can find a somewhat larger number of sex discrimination cases resolved in plaintiffs' favor on these grounds, including the decision of the D.C. Circuit in Price Waterhouse. See, e.g., Hopkins v. Price Waterhouse, 825 F.2d 458, 469 (D. C. Cir. 1987) (stating that unawareness of bias "neither alters the fact of its existence nor excuses it"), aff'd on other grounds sub nom. Price Waterhouse v. Hopkins, 490 U.S. 228, 109 S. Ct. 1775 (1989). See also Lynn v. Regents of the Univ. of Cal., 656 F.2d. 1337, 1343 (9th Cir. 1981) (asserting that "disdain for women's issues . . . is evidence of a discriminatory attitude towards women"); Sweeny v. Board of Trustees of Keene State College, 604 F.2d 106, $113 \mathrm{n} .12$ (1 st Cir. 1979) (sex discrimination case affirming judgment for plaintiff because the district court reasonably concluded that the decision not to promote plaintiff was based on "a subtle, if unexpressed, bias against women"). If dissents are taken into account, one more case can be added to the tally. See Namenwirth v. Board of Regents of Univ. of Wis. Sys., 769 F.2d 1235, 1250-51(7th Cir. 1985) (Swygert, J., dissenting) (stating "[s]ex bias need not be conscious to be actionable. The most likely explanation for the events at bar is that [plaintiff] was scrutinized by the Department because she was breaking new ground .... In short, given [plaintiff's] unhappy role as a pathbreaker, she had to perform better than a male to succeed. Such unequal treatment-however unconscious or subtle-violated Title VII.").

78. We have been able to find only one post-Price Waterhouse disparate treatment case that acknowledged that the unconscious application of cognitive stereotypes may result in discrimination 
circuit court decisions remanding "subtle bias" dispositions in plaintiffs' favor to the district court for "clarification" on the issue of conscious discriminatory intent. ${ }^{79}$ The relative dearth of supporting case law provides Title VII plaintiffs and their counsel with powerful incentive against premising a disparate treatment case on the application of subtle or unconscious forms of intergroup bias. This results, we suggest, in a growing disjunction between the way in which intergroup bias is understood in the social sciences, or by members of minority groups who have experienced it, and the way it is described in disparate treatment case law and modeled in disparate treatment doctrine.

Curiously, one finds in cases under the Age Discrimination in Employment $\mathrm{Act}^{80} \mathrm{a}$ clear and longstanding judicial recognition that age discrimination can result from the operation of subtle, unconscious mental processes and that, for this reason, the critical inquiry in an age-based disparate treatment case centers on the question of causation, not the question of conscious intentionality. As the Supreme Court has held, to prove first-tier liability under the ADEA, ${ }^{81}$ a plaintiff need only prove that her age "played a role in the decision" and "had a determinative influence on

and then, on this basis, ruled for the plaintiff. Thomas v. Eastman Kodak Co., 183 F.3d 38 (1st Cir. 1999).

79. For example, in EEOC v. Cherry-Burrell Corp., 35 F.3d 356, 363 (8th Cir. 1994), the circuit court reviewed a district court decision finding in favor of a Title VII sex discrimination plaintiff on the grounds that the alleged compensation discrimination resulted from subconscious bias. Noting that Title VII "requires a finding of intentional misconduct, not subconscious unlawful action," the Court of Appeals remanded the case to the district court for "clarification" on the question of intent to discriminate. The court's thinly veiled directive to the district court was plain: if you want this decision to stand on appeal, go back and find conscious intent to discriminate.

Similarly, in a recent race discrimination case, Ferrill v. Parker Group, Inc., 168 F.3d 468 (1 1 th Cir. 1999), the circuit court conceded that, to prove discriminatory intent, a disparate treatment plaintiff need not show that the defendant harbored some special malice or hostility toward the group to which plaintiff belonged. However, the court stressed that to prevail on remand, the plaintiff would have to prove that the defendant "consciously and intentionally made job assignments based on racial stereotypes." 168 F.3d at 473 n.7 (emphasis added).

A similar understanding of actionably discriminatory stereotyping as a conscious rather than subconscious process is displayed in E.E.O.C. v. Joe's Stone Crab, Inc., 220 F.3d 1263 (11th Cir. 2000). As earlier described, the circuit court premised its decision to remand the case for further findings on the issue of discriminatory intent on the observation that, in hiring food servers, defendant had apparently applied the stereotyped notion that "classy" restaurants employ male waiters, not female waitresses. In providing guidance to the district court, the circuit court was careful to characterize such stereotyping as a conscious process. Specifically, Judge Marcus explained that, "if Joe's deliberately and systematically excluded women from food server positions based on a sexual stereotype which simply associated 'fine dining ambience' with all-male food service, it then could be found liable under Title VII for intentional discrimination . ..." 220 F.3d at 1284 (emphasis added).

80. 29 U.S.C. $\$ 621$ (1988).

81. The A.D.E.A. establishes two tiers of liability. Under the first tier, an employer can be held liable for damages for a simple violation of the Act, which makes it unlawful for an employer "to fail or refuse to hire or to discharge any individual or other discriminate against any individual with respect to his compensation, terms, conditions, or privileges of employment, because of such individual's age." 29 U.S.C. $\$ 623$ (a) (1988). Under the second tier, an employer can be held liable for liquidated, or double damages, if it committed a "willful" violation. 29 U.S.C. $\$ 626(b)$ (1988). 
the outcome." 82 Many lower courts applying this standard have made clear that it requires a causal inquiry, not an inquiry into the decision maker's conscious mental state. In Burlew v. Eaton Corp. ${ }^{83}$ for example, the Seventh Circuit carefully distinguished between motive, which the court defined as a causal construct, and conscious intent to discriminate. Stated the Burlew court:

This standard-that age was a determining factor-does not in itself require a finding as to defendant's state of mind, for in law there is a distinction between motive and intent. "Motive is what prompts a person to act, or fail to act. Intent refers only to the state of mind with which the act is done or omitted." Indeed, in 1981, we stated:

Congress, in our opinion, intended that liability under the ADEA could be established without any showing as to the defendant's state of mind. ${ }^{84}$

Along these lines, numerous circuit courts have acknowledged that "age discrimination may simply arise from an unconscious application or stereotyped notions of ability rather than from a deliberate desire to remove older employees from the workforce" and on that basis have ruled in the plaintiff's favor. ${ }^{85}$

As these decisions recognize, requiring proof of conscious intent to discriminate would lead to the significant under-identification of cases inawhich protected group status has "played a role in the decision" and has had "a determinative influence on the outcome." This standard is, on its face, unambiguously causal in focus. ${ }^{86}$ If a plaintiff's race or sex caused an employment action to occur, then liability should be present, even if the decision maker was unaware that he was taking the prohibited factor into account. That "unconscious" discrimination frequently occurs is well documented; many people are unaware that race or sex has influenced their assessment of an individual. ${ }^{87}$ Most of us like to

82. Hazen Paper Co. v. Biggins, 507 U.S. 604,113 S. Ct. 1701 (1993).

83. 869 F.2d 1063 (7th Cir. 1989).

84. Id. at 1066 (quoting Black's Law Dictionary 727 (5th ed. 1979)).

85. Spyvock v. Milwaukee Boiler Mfg. Co., 665 F.2d 149, 155 (7th Cir. 1981) (quoting 113 Cong. Rec. 34, 742 (1967) (remarks of Rep. Burke)). Accord Brooks v. Woodline Motor Freight, 852 F.2d 1061, 1064 (8th Cir. 1988) (citing Spyvock for the proposition that unconscious stereotypes often cause race discrimination); Oxman v. WLS-TV, 846 F.2d 448, 453 (7th Cir. 1988) (same); La Montagne v. American Convenience Prods., Inc., 750 F.2d 1405, 1410 (7th Cir. 1984) (stating that "[a]ge discrimination may be subtle and even unconscious."); McCormistin v. United States Steel Corp., 621 F.2d 749, 754 (5th Cir. 1980) (stressing the subtlety of age discrimination). Various recent applications of this principle can be found as well. See e.g., Oberg v. Allied Van Lines, No. 91-C6576, 1996 U.S. Dist. LEXIS 4717 (N.D. Ill. 1996) (stating that age discrimination may result from the unconscious application of stereotypes); See also In re Interco, Inc., 211 BR 667, 680 (1997) (age discrimination case adjudicated in federal bankruptcy court finding in plaintiff's favor and observing that "age discrimination is often subtle and may arise from an unconscious application of stereotyped notions of ability.").

86. See supra discussion in text accompanying notes 81-85.

87. Krieger, supra note 22. See also McGinely, supra note 22; Tracy Ambinder Baron, Comment, Keeping Women Out of the Executive Suite: The Court's Failure to Apply Title VII Scrutiny to Upper-Level Jobs, 143 U. Pa. L. Rev. 267 (1994) (asserting that discrimination against women in 
think of ourselves as unbiased persons free from the influence of prejudices or stereotypes, but the reality is that few, if any, of us are. ${ }^{88}$ A causation-driven inquiry would not focus on whether the decision maker was aware that he was basing his decision on race, but on whether the plaintiff's race in fact caused the decision to be made, in whole or in part. ${ }^{89}$

The "reversing the groups" test, initially identified by Professor Strauss and later endorsed by Professor Selmi, provides a useful way of thinking about causation..$^{90}$ Professor Strauss asks, "Would the same decision at issue have been made were the plaintiff white?" If not, then intentional discrimination has been established. ${ }^{11}$ In the sex discrimination context, the plaintiff must show that she would have been treated differently if she had been a man. If this showing is made, it follows that her sex caused the action to occur.

This test is apt where the plaintiff must prove "but-for" causation. However, when race, sex, color, national origin or religion need only be a "motivating factor," and not the "but-for" cause of a decision, ${ }^{92}$ Professor Strauss's test is too narrow. In cases where Section 703(m) applies, a causal nexus short of but-for causation will suffice. $^{93}$

But how can the requisite degree of causation be shown when the use of race or sex was unconscious? Frankly, the same way it is shown when the use of race or sex is consciously used as a factor but untruthfully denied by the employer and its agents. ${ }^{94}$

upper-level positions is "often unintentional and unconscious.").

88. Krieger, supra note 22. See also Linda Hamilton Krieger, Civil Rights Perestroika: Intergroup Relations After Affirmative Action, supra note 43, at 1281 (discussing processes of stereotype acquisition in early childhood).

89. Welch, supra note 22, at 778. As described by Professor Selmi:

What the Court means by intent is that an individual or group was treated differently because of race. Accordingly, a better approach is to concentrate on the factual question of differential treatment. In this way, the key question is whether race made a difference in the decisionmaking process, a question that targets causation, rather than subjective mental states.

Selmi, supra note 22, at 289. Moreover, as Professors Lee \& Bhagwat have explained, in discussing the meaning of intent in equal protection cases, if a plaintiff can prove an action was "because of" his race, "to ask the plaintiff to further prove that the state actor was consciously aware of this factor imposes an almost insurmountable burden of proof (except in the rare instance where the decisionmaker admits the awareness). It also is not clear what policies would be advanced by such a requirement." Lee \& Bhagwat, supra note 22, at 154.

90. Strauss, supra note 22, at 960 ; Selmi, supra note 22, at 291.

91. Strauss, supra note 22, at 939. ("A court applying the discriminatory intent standard should ask: suppose the adverse effects of the challenged government decision fell on whites instead of blacks, or on men instead of women. Would the decision have been different? If the answer is yes, then the decision was made with discriminatory intent." This test, as Professor Strauss notes, reaches both conscious and unconscious discrimination. Id. at 956, 960 .

92. See supra notes $64-68$ and accompanying text.

93. See supra notes $64-65$ and accompanying text.

94. See Krieger, supra note 22, at $1241-42$ (suggesting that, under a causation approach to disparate treatment proof, the same evidence used to prove covert intentional discrimination would be used to prove cognitive bias, the primary difference between the two regimes being the inferences drawn from particular facts); Selmi, supra note 22 (recognizing that the Court's proof structure in circumstantial evidence should support a disparate treatment claim in cases involving "subtle or 
The evidentiary structure developed in circumstantial evidence cases, as most recently confirmed in Reeves, is designed to allow a fact finder to determine whether race, sex, etc. in fact played a role, perhaps a determinative role, in an employment decision when the employer has denied taking the factor into account. ${ }^{95}$ The evidence underlying the prima facie case, the strength or weakness of the reason articulated by the employer, evidence that the articulated reason is untrue and/or did not truly motivate, differences in the treatment of others similarly situated to the plaintiff, and past treatment of the plaintiff, and expressions of animus or bias by the decision maker are all useful in determining whether the protected characteristic motivated a decision. ${ }^{96}$ What differs is not the nature of the evidence proffered to prove that discrimination did or did not occur. Rather, what differs is the range of inferences that a court is able to draw, or to instruct a jury to draw, from that evidence.

This follows because a causation approach to discrimination incorporates a broader and more complete positive account of intergroup bias. It recognizes that many types of bias, often operating outside of conscious awareness, can distort an employer's judgment and cause him or her to discriminate based on an applicant or employee's protected group status. Because the causation approach is based on a more complete descriptive theory of intergroup bias, it provides a better-elaborated "inferential architecture" for the structure of disparate treatment adjudication.

Thinking about intentional discrimination in the context of vertical or horizontal decision making powerfully illustrates the normative superiority of the causation approach to disparate treatment proof. As we will demonstrate, in the context of both vertical and horizontal multi-agent decision making, a causation-based analysis is not only the most sensible way of thinking about discriminatory motivation, it is the only sensible way of approaching the issue.

\section{VERTICAL DECISION MAKING}

Disparate treatment claims in which the supervisory employee who acted for a wrongful purpose is not the person who actually terminates the plaintiff are common. Employer liability in such cases should depend on the answers to two questions: first, whether there was a causal link between the protected characteristic and the challenged decision; and second, whether in light of the chain of causation, the wrongfully motivated action is attributable to the employer, either directly or vicariously.

\section{A. The Causation Inquiry}

The easiest cases, and those shedding little light on the issue of unconscious discrimination or of how best to solve the multiple actor puzzle, are those in which a supervisor motivated by invidious animus was the de facto decision maker, even

unintentional discrimination."); McGinley, supra note 22, at 447 (asserting that current disparate treatment proof methods "are all capable of holding liable employers who have discriminated unconsciously as well as those who have done so consciously.").

95. McGinley, supra note 22, at 484-85.

96. Id. 
though someone higher in the organizational hierarchy actually fired the plaintiff. The firing decision in these cases is simply a rubber stamp. Courts have properly refused to allow defendants to escape liability simply because the individual who executed the termination decision had no intent to discriminate if the actual decision maker acted unlawfully. When the formal decision maker is essentially "the cat's paw" ${ }^{\text {"97 }}$ of a discriminating supervisor, for example, the supervisor's unlawfully motivated recommendation should be a sufficient basis for imposing liability on the employer for the termination..$^{98}$

Reeves exemplifies cases of this type. Although Sanderson, not Chestnut, fired Reeves, the "actual decision maker," according to the Court, was Chestnut."9 Therefore, his age-based recommendation to fire Reeves was the functional equivalent of an age-based termination. Sanderson merely executed the decision Chestnut had made, and thus, once the Court was convinced that there was sufficient evidence that age motivated Chestnut's decision, imposing liability on the company followed as a matter of course.

Other scenarios are more difficult. Suppose a supervisor recommends a job action, such as termination, because of an employee's race or sex. But suppose further that the ultimate decision maker does not simply rubber stamp the recommendation but does take the impermissibly motivated recommendation into account in reviewing the facts and making the final decision.

If the ultimate decision maker is aware that the recommendation was improperly motivated, then imposing liability on the employer readily follows. That essentially was the situation operating in Price-Waterhouse; some partners had made recommendations against Ann Hopkins that were overtly biased. ${ }^{100}$ The firm's decision to accept those recommendations as part of the decison making process was enough to find that Hopkins's sex was a motivating factor in the decision to deny her partnership. ${ }^{101}$

Lower courts have followed the Supreme Court's lead. For example, in Barbano v. Madison County, statements by one hiring committee member that he would not consider "some woman" for the job was enough to impute liability to the Board, when the Board's "hiring decision was made in reliance upon a discriminatory recommendation." 102 The court rejected the argument that the

97. "Other circuits have recognized that a defendant may be held liable if the manager who discharged the plaintiff merely acted as a rubber stamp, or the 'cat's paw,' for a subordinate employee's prejudice, even if the manager lacked the discriminatory intent." Kendrick v. Penske Transp. Serv., Inc., 220 F.3d 1220,1231 (10th Cir. 2000) (collecting cases and agreeing with analysis); Willis v. Marion County Auditor's Office, 118 F.3d 542 (7th Cir. 1997).

98. Kendrick v. Penske Transp. Serv., Inc., 220 F.3d 1220,1231 (10th Cir. 2000); Willis v. Marion County Auditor's Office, 118 F.3d 542 (7th Cir. 1997).

99. 530 U.S. 133, 120 S. Ct. 2097 (2000).

100. 490 U.S. 228, 109 S. Ct. 1775 (1989).

101. Id. See also Anderson v. Bessemer City, 470 U.S. 564, 105 S. Ct. 1504 (1985) (discriminatory statements and actions by some committee members during hiring process supported finding of sex discrimination by city).

102. 922 F.2d 139, 143 (2d Cir. 1990). The Barbano court expressly relied upon Price Waterhouse in reaching this result. 
Board's decision itself was not tainted, as it made no effort to distance itself from the discriminatory statements. ${ }^{103}$ And more recently in Hunt v. City of Markham, statements by a black mayor that the "city needed to get rid of all the old white police officers" were admitted to prove that the city council's decision was discriminatory. ${ }^{104}$ Even though the mayor had no vote, he made recommendations to the city council on the decision at issue. "Emanating from a source that influenced the personnel action (or nonaction), the derogatory comments are evidence of discrimination."

Often, however, a tainted recommendation will be facially neutral, and the ultimate decision maker will be unaware that it was based on the employee's protected status. Will employer liability be found in those circumstances?

Most courts say yes. ${ }^{106}$ Rather than focusing on whether the ultimate decision maker acted because of the employee's race, sex or age, these courts use a causation approach in determining whether employer liability exists. They examine whether there is a break in the chain of causation between the supervisor's impermissibly motivated action and the ultimate decision being challenged by the employee. ${ }^{107}$ If the chain of causation is intact, liability is imposed, even when the ultimate decision maker himself acted with no intent to discriminate.

In Willis v. Marion County Auditor's Office, for example, the Seventh Circuit described this causation-based approach for imputing a subordinate employee's motivation to the employer. ${ }^{108}$

Our cases have noted that this situation may occur in an instance in which a subordinate, by concealing relevant information from the decisionmaker, is able to manipulate the decisionmaking process and to influence the decision. These cases prevent an employer from escaping liability by

103. Id. at 143. "This knowing and informed toleration of discriminatory statements by those participating in the interview constitutes evidence of discrimination by all those present," said the court, further finding that the discriminatory interview had affected the hiring process, as "the Board's hiring decision was made in reliance upon a discriminatory recommendation." Id. For a discussion of the Barbano case and others like it, see Gerken, supra note 66.

104. 219 F.3d 649, 652 (7th Cir. 2000).

105. Id. at 653 .

106. Wallace v. SMC Pneumatics, Inc., 103 F.3d 1394 (7th Cir. 1997); Willis v. Marion County Auditor's Office, 118 F.3d 542 (7th Cir. 1997); Long v. Eastfield College, 88 F.3d 300 (5th Cir. 1996); Abrams v. Lightolier, Inc., 50 F.3d 1204 (3d Cir. 1995); Gusman v. Unisys Corp., 986 F.2d 1146 (7th Cir. 1993); Kientzy v. McDonnell Douglas Corp., 990 F.2d 1051 (8th Cir. 1993); Simpson v. Diversitech Gen. Inc., 945 F.2d 156 (6th Cir. 1991); Jiles v. Ingram, 944 F.2d 409 (8th Cir. 1991); Shager v. Upjohn Co., 913 F.2d 398 (7th Cir. 1990).

107. See, e.g., Willis v. Marion County Auditor's Office, 118 F.3d 542 (7th Cir. 1997) (when the causal relationship between the discriminatory motive of the biased decisionmaker is broken, then ultimate decision to terminate is permissible. Otherwise, the jury may impute motive of the biased subordinate to the company); Long v. Eastfield College, 88 F.3d 300 (5th Cir. 1996) (question is whether chain of causation between supervisor's bias and president's decision was broken); Shager v. Upjohn Co., 913 F.2d 398 (7th Cir. 1990) (liability depends upon whether causal link between supervisor's prejudice and committee's decision has been severed).

108. 118 F.3d 542 (7th Cir. 1997). 
setting up many layers of pro forma review, thus making the operative decision that of a subordinate with an illicit motive. In such a case, a jury may impute the discriminatory motive of the biased subordinate, as opposed to the motives of the ignorant decisionmaker, to the company. ${ }^{109}$

However, the court noted, when the causal relationship between the motive and the ultimate decision is broken, then the subordinate's bias is considered irrelevant. ${ }^{110}$

Similarly, in Griffin v. Washington Convention Center, the court reversed a magistrate's decision to exclude evidence that plaintiff's immediate supervisor was opposed to women working as electricians. ${ }^{11}$ The defendant had argued that the evidence was irrelevant, since a supervisor higher in the decision making chain, herself a woman, had made the ultimate decision to fire the plaintiff. ${ }^{112}$ But exclusion of the evidence was reversible error, the court stated, as it "would permit a reasonable jury to infer that [plaintiff] lost her job on account of her sex" because the termination decision was not "independent of, or insulated from" the immediate supervisor's input. ${ }^{113} \mathrm{He}$ had made complaints about the plaintiff and had designed, provided and evaluated the plaintiff's training program. "Thus do we join at least four other circuits in holding that evidence of a subordinate's bias is relevant where the ultimate decision maker is not insulated from the subordinate's influence," said the court. ${ }^{114}$

The vertical decision making cases, with their overt focus on causation, demonstrate the lower courts' awareness that, at least in this context, disparate treatment cases center on a causal inquiry. But these cases do not answer directly the more subtle question of what must cause, in whole or in part, the employment action at issue. Must some agent of the employer consciously take race, sex, or age into account in order for race, sex, or age to cause the decision to occur? Or need the plaintiff only show that her race, sex or age in fact caused the decision to occur, whether or not she can show a conscious use of race, sex or age in the decisionmaking process?

In the vertical decision making cases discussed above, it is proved, or assumed, that a supervisory employee acted out of animus or bias. ${ }^{115}$ That bias or animus may

109. Id. at 547.

110. Id. See Kendrick v. Penske Transp. Serv., Inc., 220 F.3d 1220, 1232 (10th Cir. 2000) (independent investigation and review broke chain of causation).

111. 142 F.3d 1308 (D.C. Cir. 1998).

112. Id. at 1311 .

113. Id. at 1313 .

114. Id at 1312. See Santiago-Ramos v. Centennial P.R. Wireless, Corp., 217 F.3d 46 (1st Cir. 2000) (discriminatory statements by those in a position to influence key decision maker may be used to show pretext); Hunt v. City of Markham, 219 F.3d 649 (7th Cir. 2000) (statements made by decision makers or those who provide input into the decisionmaking process are evidence of discrimination).

115. See, e.g., Griffin v. Washington Convention Ctr., 142 F.3d 1308 (D.C. Cir. 1998) (plaintiff's supervisor opposed to women working as electricians); Santiago-Ramos v. Centennial P.R. Wireless Corp., 217 F.3d 46 (1st Cir. 2000) (supervisor doubted women with children being able to do job); Hunt v. City of Markham, 219 F.3d 649 (7th Cir. 2000) (mayor stated city "needed to get rid of all the old white police officers"). 
take any number of forms and may taint the overall decision-making process in a number of ways. As in Griffin v. Washington Convention Center, ${ }^{116}$ the supervisor may object to members of plaintiff's social group (women) serving in particular occupational roles (electricians), and for that reason attempt to find ostensibly non-discriminatory reasons for removing members of the disfavored group from the jobs at issue. As in Santiago-Ramos v. Centennial P.R. Wireless, ${ }^{117}$ the supervisor may simply believe, as an empirical matter, that members of a certain social group (women with children) are not generally successful in particular positions. Or, as in Hunt $v$. City of Markham, ${ }^{118}$ an individual wielding influence over personnel decisions (the mayor) may simply seek to provide jobs to members of his own social reference group (African American men). In short, the biased supervisors whose recommendations ultimately result in a negative employment action can be motivated by normative stereotypes, ${ }^{119}$ cognitive stereotypes, ${ }^{120}$ or simple in-group preferences.

Once they have determined that a biased, lower level supervisor had an opportunity to influence the ultimate decision, these courts ask whether that ultimate decision was sufficiently insulated from that animus or bias. An invidiously motivated supervisor can, of course, influence a decision made higher up the organizational hierarchy in a number of different ways. So, as the Seventh Circuit observed in Wallace v. SMC Pneumatics, Inc., ${ }^{121}$ a biased supervisor may conceal relevant information or even fabricate evidence, thus depriving the ultimate decision maker of an accurate data set on which to base a final judgment. Or, as Professor Sullivan has observed, ${ }^{122}$ a biased employee with input into the decision making process may influence that process simply by putting a certain "spin" on decision-relevant events.

Whatever the nature of the distortion introduced by the biased subordinate, courts look to see if the taint injected into the process was removed before the ultimate decision was made. If not, liability is imposed. If the defect was corrected, thereby breaking the causal chain, the employer is excused from

116. 142 F.3d 1308 (D.C. Cir. 1998) (supervisor opposed to the idea of women working as electricians).

117. 217 F.3d 46 (1st Cir. 2000) (supervisor did not believe that a woman with a child would be capable of doing the job).

118. 219 F.3d 649 (7th Cir. 2000) (mayor stated that, to solve certain problems, the city "needed to get rid of all the old white police officers").

119. By "normative stereotypes" we mean social role expectations, such as the belief that "women should not be electricians." See Krieger, supra note 43, at 1278.

120. "Cognitive stereotypes" are knowledge structures-implicit expectancies that membership in a particular social group is predictive of past or future behavior, or of particular traits, abilities, or aptitudes. See id.

121. 103 F.3d 1394 (7th Cir. 1997).

122. See Sullivan, supra note 7, at 1139 n.117("Even if B faithfully reviews A's recommendations, A may be able to skew B's decision by the way in which he presents (or fails to present) data. This may range from putting the preferred 'spin' on the recommendation to fabricating evidence concerning the candidate."). 
liability. ${ }^{123}$

Although these cases do not directly stand for the proposition that the unconscious use of a protected characteristic can result in a viable disparate treatment claim, indirectly, they support that view. The courts in these cases are not asking whether the person who fired the plaintiff was aware that group status was playing a role in the outcome. They accept that even in the absence of such awareness a disparate treatment claim may exist. In other words, for liability to attach, the person who fires the plaintiff need not intend to make the decision because of the plaintiff's group status, if group status in fact played a causal role in the decision making process.

There are strong parallels between how, in the vertical decision making context, a biased actor operating lower in the organizational hierarchy chain can cause a discriminatory decision to be made higher up and how, in single actor situations, unconscious stereotypes can cause discrimination even in the absence of conscious intent to discriminate. In light of these parallels, there is no sound basis for centering the inquiry on causation in vertical decision making contexts while searching single-mindedly for conscious intent to discriminate in single actor situations. In the single decision maker context, cognitive stereotypes can function in precisely the same way as does the invidiously motivated supervisor in vertical decision making situations, distorting the data set on which a decision will be based and putting a particular, stereotype-reinforcing "spin" on decision-relevant information. Extending the analogy, to prevent stereotypes from tainting her judgment and ultimately causing her to discriminate, the single decision maker-like the ultimate decision maker in a vertical, multi-actor context-must take affirmative steps to insulate herself from the effects of bias. To see how and why this is so, we must do a little cognitive psychology.

A stereotype is best understood as a type of schema. A schema, in turn, is best understood as a "knowledge structure,"124 a network of interrelated elements representing a person's knowledge, beliefs, experiences (both direct and vicarious), and expectancies relating to the schematized object. ${ }^{125}$ As many social psychologists have demonstrated, people learn at a very early age the stereotypes associated with the major social groups in the United States. ${ }^{126}$ These stereotypes have a long history of activation and are likely to be highly salient, regardless of whether or not they are believed by the person holding them. ${ }^{127}$

123. See Kendrick v. Penske Transp. Serv., Inc., 220 F.3d 1220 (10th Cir. 2000).

124. Richard E. Nisbett \& Lee Ross, Human Inference: Strategies and Shortcomings of Social Judgment 6-7 (1980).

125. See generally. William F. Brewer \& Glenn V. Nakamura, The Nature and Function of Schemas, in 1 Handbook of Social Cognition 119 (Robert S. Wyer \& Thomas K. Srull, eds. 1984) (providing an overview of schema theory, particularly as it relates to social cognition).

126. See generally Patricia G. Devine, Automatic and Controlled Processes in Prejudice: The Role of Stereotypes and Personal Beliefs, in Attitude Structure and Function 181, 182-84 (Anthony R. Pratkanis et al. eds., 1989) (collecting sources). See also Phyllis A. Katz, The Acquisition of Racial Attitudes in Children, in Towards the Elimination of Racism 125 (Phyllis A. Katz ed., 1976)(describing processes of stereotype acquisition in pre-school age children).

127. See generally Patricia G. Devine, Stereotypes and Prejudice: Their Automatic and 
Stereotypes, like other schemas, are automatically triggered when people encounter a member of a stereotyped group. Once triggered, the stereotype "primes" or "activates" the various trait constructs and other features with which it is associated. ${ }^{128}$ It is useful to think of a stereotype as a network of associations, that, once primed, "lights up" in the mind and prepares to "get to work."

Stereotypes can covertly, but powerfully, influence the way information about a stereotyped person is processed and used. Stereotypes shape the interpretation of incoming information, ${ }^{129}$ determine the manner in which that information is encoded into memory ${ }^{130}$ and the ease with which it is retrieved from memory, ${ }^{131}$ and they affect the way information, once retrieved, is used in making judgments about a stereotyped person at a later point in time. ${ }^{132}$

Cognitive stereotypes often function not as consciously held beliefs, but as implicit expectancies. Through the mediation of various mental processes, functioning largely outside of conscious awareness, ${ }^{133}$ a stereotype, like an invidiously motivated supervisor reporting to his superior, covertly biases the data on which a social judgment will be made, skewing that judgment in a stereotypereinforcing direction.

Single actor decisions influenced by stereotypes are, in this sense, little different than decisions made in vertical multiple actor contexts. Bias intrudes into the decision making process not through a conscious intent to discriminate when the ultimate decision is made, but much earlier, as information about the stereotyped person is being attended to, interpreted, encoded into and retrieved from memory, and combined with other information to make a final decision. This is an important point. Single actor decisions, like their vertical, multi-actor counterparts, are not made at a discrete moment in time. The Price-Waterhouse plurality's characterization to the contrary, there is, as a matter of good social science, no real

Controlled Components, $56 \mathrm{~J}$. Personality \& Soc. Psychol. 5, 6-7 (distinguishing stereotypes from beliefs).

128. Devine, supra note 127, at 3-9.

129. H. Andrew Sagar \& Janet Ward Schofield, Racial and Behavioral Cues in Black and White Children's Perceptions of Ambiguously Aggressive Acts, 39 J. Personality \& Soc. Psychol. 590 (1980) (demonstrating that precisely the same behaviors were interpreted as either "playful" and "friendly," or "mean" and "aggressive," depending on whether the actor was black or white).

130. Myron Rothbart et al., Recall for Confirming Events: Memory Processes and the Maintenance of Social Stereotypes, 15 J. Experimental Soc. Psychol. 343 (1979) (demonstrating that stereotype-consistent information is encoded into memory in a way that makes it easier to recall than stereotype-inconsistent or stereotype-irrelevant information).

131. Id. See also Nancy Cantor \& Walter Mischel, Prototypicality and Personality: Effects on Free Recall and Personality Impressions, 13 J. Res. in Personality 187, 188-92 (1979) (replicating Rothbart, Evans \& Fulero and exploring issues relating to retrieval from memory).

132. Galen V. Bodenhausen \& Robert S. Wyer, Jr., Effects of Stereotypes on Decision Making and Information-Processing Strategies, 48 J. Personality \& Soc. Psychol. 267 (1985) (demonstrating that subjects are more likely to attribute stereotype-consistent transgressions to stable traits, and for that reason tend to judge the transgression as more likely to recur and therefore to impose a harsher penalty than when the same transgression is committed by a non-stereotyped person).

133. John Kihlstrom refers to these functions as the "cognitive unconscious." John F. Kihlstrom, The Cognitive Unconscious, in 237 Science 1445 (1987). 
"moment of decision"134 in any social judgment situation. Rather, social judgment and decision making is always an integrated system comprising attention, perception, interpretation, attribution, memory, and ultimate judgment. Stereotypes bias social judgment quite early in this process, and can cause even a wellintentioned decision maker to take an action or make a decision "based on" the target's protected group membership.

In short, even when an employment decision is made by a single actor, decision making proceeds in a sequence of functional stages. The structure of this sequence, and the functions being performed at each stage, are similar in many respects to the structure of vertical decision making in organizations. As many organization behavior theorists have observed, organizations process information in stages and exhibit information processing strategies closely analogous to those performed by individuals. $^{135}$

Along these lines, Patricia Corner and her colleagues have proposed a "parallel process model" comparing individual and organizational decision making. This model breaks the organizational decision making process down into five stages closely resembling the sequenced nature of social judgment described by social cognition theorists. These stages include: (1) attention/perception, (2) interpretation/encoding, (3) storage/retrieval, (4) choice, and (5) outcome. In many vertical decision making situations, the attention, interpretation/encoding, and storage/retrieval functions are performed by lower-level supervisors, whereas the choice and outcome functions are performed higher up the organizational hierarchy, often following a supervisor's report and recommendation. Biases influencing perception and judgment on the supervisor's part, or otherwise corrupting the "record" of information stored and made available to decision makers functioning higher in the vertical chain, if not corrected, lead to results as clearly tainted by bias as it would be in cases involving a biased individual decision maker.

For this reason, the vertical decision making cases are particularly useful in understanding how we should think about discriminatory motivation in single actor situations. Rather than a search for conscious discriminatory intent, the inquiry in a disparate treatment cases should focus on whether race, sex, national origin, or age in fact caused the decision to occur, in whole or in part. ${ }^{136}$ Just as an ultimate

134. The plurality opinion in Price Waterhouse states:

The present, active tense of the operative verbs of $\$ 703$ (a)(1) ("to fail or refuse") ... turns our attention to the actual moment of the event in question, the adverse employment decision. The crucial inquiry, the one commanded by the words of $\$ 703(\mathrm{a})(1)$, is whether gender was a factor in the employment decision at the moment it was made.

Price Waterhouse v. Hopkins, 490 U.S. 228, 240-41, 109 S. Ct. 1775, 1785 (1989).

135. Patricia Doyle Comer, et al., Integrating Organizational and Individual Information Processing Perspectives on Choice, in Cognition Within and Between Organizations 145 (James R. Meidl et al., eds., 1996); D.A. Gioia, Symbols, Scripts, and Sensemaking: Creating Meaning in the Organizational Experience, in The Thinking Organization: Dynamics of Organizational Social Cognition 49 (J.P.Sims, et. al., eds., 1986); B. Levitt \& J. G. Marsh, Organizational Learning, in Annual Review of Sociology 319 (W.R. Scott \& J. Black, eds., 1988).

136. Importantly, the degree of causation required under employment discrimination laws, as mentioned earlier, is uncertain and may vary depending upon the statutory claim. Section $703(\mathrm{~m})$ of 
decision maker in a vertical chain may be unaware of a subordinate's animus, an individual decision maker may be unaware of the effect of implicit stereotypes on his or her own social judgment. But that unawareness, whether it occurs in the context of multi-level decision making or in the context of a single decision maker, does not mean the protected characteristic has not in fact caused the decision to occur. And when it has, disparate treatment based on the protected characteristic has occurred as well.

\section{B. Employer Liability for Discrimination: The Vicarious Liability Inquiry}

Finding a causal link between a protected characteristic and a challenged decision may establish disparate treatment, but it may not necessarily establish a viable disparate treatment claim. The disparate treatment must be attributable to an employer, either directly or vicariously, before the employer may be held liable for it. Although the courts in multiple actor cases usually have not coupled their discussion of causation with an analysis of vicarious liability principles, ${ }^{137}$ the decisions may be best understood on that basis.

A recent decision from the Tenth Circuit, Kendrick $v$. Penske Transportation Services, Inc., aptly demonstrates this point. ${ }^{138}$ There, Tirrell, a low level supervisor, reported that the plaintiff had shoved and verbally abused him. That complaint was investigated by another supervisor, Levine, who gave plaintiff an opportunity to respond. Plaintiff refused to respond. The investigating supervisor then recommended to the company's Human Resource manager, Cash, that plaintiff be terminated based on the alleged misconduct. The manager accepted that recommendation and fired the plaintiff. ${ }^{139}$ Even assuming the allegations of misconduct were untrue and that Tirell's decision to complain was racially motivated, the court found insufficient evidence of discrimination. Noting that plaintiff had been given, and had rejected, an opportunity to respond to Tirrell's allegations, the court found insufficient evidence of discrimination. As the court noted:

Kendrick has provided no evidence to show that Levine's investigation was a sham or that Tirrell's allegedly discriminatory motives influenced Levine, nor does Kendrick offer any evidence that Levine or Cash acted

Title VII requires only that the protected characteristic was "a motivating factor," which appears to remove "but-for" causation as a requisite for liability. See supra notes 64-68 and accompanying text. Some courts, however, limit Section $703(\mathrm{~m})$ only to Title VII claims involving direct evidence of discrimination. Moreover, the motivating factor analysis set forth in Section 703(m) may not be available to any claims other than those arising under Section 703 , whether or not direct evidence is involved. Id.

137. But see Long v. Eastfield College, 88 F.3d 300, 306 (5th Cir. 1996) (recognizing "the overlap of issues of causation and agency" in determining whether a university could be liable for discrimination when a supervisor with animus recommended termination but the college president who made the decision did not).

138. 220 F.3d 1220 (10th Cir. 2000).

139. Id. at 1223-24. 
upon a discriminatory motive in their own right. The undisputed evidence shows that Cash discharged Kendrick based on Levin's report that [plaintiff] pushed and verbally abused Tirrell. ${ }^{140}$

Were causation the only element needed for a discrimination claim, the Kendrick case would seem wrongly decided. Had plaintiff not been black, he would not have been accused of misconduct. And had those accusations not been made, he would not have been the subject of an investigation that ultimately resulted in his discharge. Thus, Kendrick's race would seem to be at least a motivating factor, if not the but-for cause, of his termination.

Yet the Kendrick decision, on the facts found by the court, is probably correct. ${ }^{141}$ This is so because the only act that was assumed to have been impermissibly motivated was the accusation of shoving and verbal abuse. But that accusation was not self-enforcing. Instead, it merely triggered an investigation into Kendrick's conduct. ${ }^{142}$ The investigation itself was found to have been conducted in a nondiscriminatory manner, and it was the recommendation coming out of the investigation that led to Kendrick's discharge. ${ }^{143}$ Since no action properly attributable to the employer was the product of an intent to discriminate, imposing liability on Kendrick's employer might well have been impermissible under the vicarious liability standards articulated by the Supreme Court.in Burlington Industries, Inc. v. Ellerth. ${ }^{144}$

In Ellerth, the Supreme Court for the first time explained the theories underlying vicarious employer liability for discrimination under federal employment discrimination statutes. ${ }^{145}$ When a supervisor's action is within the scope of his employment, vicarious employer liability will exist. ${ }^{146}$ To be within the scope of employment, however, the act must be motivated, at least in part, by a purpose to serve the employer's interests. ${ }^{147}$ Sometimes, decisions that are the product of an

140. Id. at 1231-32.

141. This statement is limited to the court's analysis of the multiple actor issue. There was additional evidence of race discrimination that appears to have been discounted by the court.

142. Id. at 1223-24.

143. Id. at 1231-32.

144. 524 U.S. 742,118 S. Ct. 2257 (1998).

145. Because the statutes define employer to include "agents" of the employer, the Court was guided by common law agency principles in fashioning its vicarious liability standards. However, the common law served merely as a guide to the Court in developing "a uniform and predictable standard" of vicarious liability under Title VII. 524 U.S. at 760, 118 S. Ct. at 2268.

Although Ellerth was a sexual harassment case, the reasoning put forward was not limited to the sexual harassment context, and many of the cases relied upon by the Court in explaining when vicarious employer liability is appropriate were disparate treatment claims not involving sexual harassment. Id. at $752-53,118 \mathrm{~S}$. Ct. at 2264 . Thus, Ellerth's reasoning should be applicable outside the sexual harassment context. See Rebecca Hanner White, There's Nothing Special About Sex: The Supreme Court Mainstreams Sexual Harassment, 7 Wm. \& Mary Bill of Rights J. 725, 743, 750-53 (1999) for elaboration of this point.

146. 524 U.S. at 756,118 S. Ct. at 2266. See also Section 219(1) of the Restatement (Second) of Agency ("A master is subject to liability for the torts of his servants committed while acting in the scope of their employment.").

147. 524 U.S. at 757,118 S. Ct. at 2266. 
intent to discriminate will not be motivated by a purpose to serve the employer's interests. ${ }^{148}$ Nonetheless, vicarious employer liability always will exist if the supervisor's impermissibly motivated conduct amounts to a tangible employment action. ${ }^{149}$ This is because the supervisor's ability to engage in the wrongful conduct necessarily will have been aided by the agency relationship. ${ }^{150}$

Importantly, the Ellerth Court expressly recognized the appropriateness of holding the employing entity liable for a supervisory employee's impermissibly motivated actions, even when the ultimate decision makers were unaware of the reasons why the supervisor acted. ${ }^{151}$ Because a tangible employment action could not occur without the delegation of authority to the supervisor, that delegation is a sufficient basis for holding the employer liable for the supervisor's wrongdoing. ${ }^{152}$

The Ellerth Court did not definitively determine what constitutes a tangible employment action. ${ }^{153}$ Ellerth has been interpreted by some courts to require a materially adverse action. ${ }^{154}$ However, when one considers the reasoning embraced in Ellerth for imposing vicarious liability, one should view a tangible job action as any action that a supervisor is empowered to engage in by virtue of his supervisory authority. ${ }^{155}$ Tangible employment actions are actions that a supervisor's status as supervisor enables him to take. ${ }^{156}$

But if the impermissibly motivated conduct is conduct that is not the exclusive province of supervisors, then vicarious liability will not exist. ${ }^{157}$ Many such cases, if they are actionable at all, would be presented as hostile work environment harassment claims. In such situations, the employer will be vicariously liable for the impermissibly motivated conduct of its supervisors only if the conduct is sufficiently severe or pervasive, and even then, the employer may assert an

148. The Court recognized this will generally be true in cases involving sexual harassment, as a supervisor who engages in sexual harassment is unlikely to be motivated in whole or in part by a purpose to serve his employer's interests. Id.

149. "[A] tangible employment action taken by the supervisor becomes for Title VIl purposes the act of the employer." Burlington Indust., Inc. v. Ellerth, 524 U.S. 742, 762, $118 \mathrm{~S}$. Ct. 2257, 2269 (1998).

150. Id.

151. As the Court stated, "A tangible employment decision requires an official act of the enterprise, a company act. The decision in most cases is documented in official company records, and may be subject to review by higher level supervisors. E.g., Shager v. Upjohn Co., 913 F.2d 398, 405 (7th Cir. 1990) (noting that the supervisor did not fire plaintiff; rather, the Career Path Committee did, but the employer was still liable because the Committee functioned as the supervisor's 'cat's-paw')." Id. at $762,118 \mathrm{~S} . \mathrm{Ct}$. at 2269.

152. Id. at 759-60, $118 \mathrm{~S}$. Ct. at 2267-68.

153. "A tangible employment action constitutes a significant change in employment status, such as hiring, firing, failing to promote, reassignment with significantly different responsibilities, or a decision causing a significant change in benefits." Id. at $761,118 \mathrm{~S}$. Ct. at 2268 .

154. See Johnson v. Booker T. Washington Broadcasting Servs., Inc., 234 F.3d 501 (1 1 th Cir. 2000) (discussing need for sufficiently adverse action).

155. The employment relationship necessarily aids the supervisor in accomplishing his wrong when a tangible employment action occurs because "there is assurance the injury could not have been inflicted absent the agency relation." 524 U.S. at 761-62, 118 S. Ct. at 2269.

156. Rebecca Hanner White, De Minimis Discrimination, 47 Emory L.J. 1121, 1155-60 (1998).

157. 524 U.S. at $762-63,118$ S. Ct. at 2269. 
affirmative defense to liability. ${ }^{158}$ If the employer had in place a procedure designed to prevent and correct the harassment and the employee unreasonably failed to take advantage of those procedures, the employer will not be liable for the supervisor's impermissibly motivated conduct. ${ }^{159}$

Under the approach we propose, other cases alleging discriminatory terms and conditions of employment, on the other hand, might lead to automatic, vicarious liability. So, for example, an employer would be held vicariously liable if a supervisor, motivated by an employee's group status, denied him equal training opportunities or job assignments, or unfairly denigrated his performance or potential in connection with a performance evaluation. These are acts that are within the supervisor's sole province, that he or she is empowered to perform by virtue of his or her position with the employer.

What does this have to do with the Kendrick decision and others like it? Actually, quite a lot. Recall that in Kendrick the only action that was assumed to have been impermissibly motivated was Tirrell's allegation that Kendrick had pushed and verbally abused him. ${ }^{160}$ Alleging that someone has engaged in physical and verbal abuse would not seem to be a tangible employment action. Such allegations presumably could be made by any employee; one need not be a supervisor to accuse someone of physical and verbal abuse. There were no allegations of the sort of severe and pervasive harassment that may result in vicarious liability when no tangible job action is present. Simply put, although Kendrick alleged that impermissibly motivated conduct had occurred, and a causal relationship between that conduct and his termination could be shown, he was unable to show impermissibly motivated conduct by his employer. Thus, he had no claim. ${ }^{161}$

Understanding the limits of vicarious liability eases concerns that causation analysis imposes liability for discrimination on a too attenuated basis. For example, in her dissent in Simpson v. Diversitech General, Inc., Judge Kennedy criticized a decision upholding employer liability when the ultimate decision maker had no discriminatory intent, arguing the "but-for" causation test is overinclusive. ${ }^{162}$ To support her point, she put forward the following hypothetical: what if a fellow employee reports a co-worker's theft because of racial animus. If the employer

158. Id. at $764-65,118 \mathrm{~S}$. Ct. at 2270 .

159. "The defense comprises two necessary elements: (a) that the employer exercised reasonable care to prevent and correct promptly any sexually harassing behavior, and (b) that the plaintiff employee unreasonably failed to take advantage of any preventive or corrective opportunities provided by the employer or to avoid harm otherwise." Id. at $765,118 \mathrm{~S}$. Ct. at 2270.

160. Kendrick v. Penske Transp. Servs., Inc., 220 F.3d 1220, 1231 (10th Cir. 2000).

161. A potential problem with this analysis, as applied to the Kendrick decision, is that the claim was brought under Section 1981, not Title VII. One need not be a statutory employer to be liable for employment discrimination under Section 1981, 42 U.S.C. $\$ 1981$ (2000), which prohibits race discrimination in the making and enforcement of contracts. However, since Kendrick did not sue Tirrell but instead sought to hold his employer vicariously liable for Tirrell's wrongdoing, it is likely the Court would apply the Ellerth rationale for vicarious liability to discrimination claims under Section 1981 .

162. 945 F.2d 156, 161-62 (6th Cir. 1991) (Kennedy, J., dissenting). 
investigates and fires the employee because of theft, "under the majority's reasoning that discharge would be 'because of' race."163

Although causation admittedly would exist, Judge Kennedy's hypothetical in fact would not, under the approach we propose, result in employer liability. While impermissibly motivated conduct causally related to a discharge would be present, there would be no impermissibly motivated conduct attributable to an employer or its agents, given that a "fellow employee" was the individual with the impermissible motive. ${ }^{164}$ Thus, the reasoning of Ellerth properly would result in a finding of no liability in Judge Kennedy's hypothetical situation. Under the actual facts of the Diversitech case, however, liability was properly imposed. Disciplinary action that was the product of a supervisor's racial animus was causally linked to the plaintiff's discharge. ${ }^{165}$ Discipline is a tangible job action that a supervisor's status as supervisor empowers him to take. ${ }^{166}$ Accordingly, because an impermissibly motivated tangible job action causally related to the discharge occurred, the employer was properly held liable for the termination.

The following year, however, Judge Kennedy was able to persuade a different Sixth Circuit panel to reject the causation based analysis followed by the Diversitech court. In Cesaro v. Lakeville Community School District, a school district decided to hire a Director of Special Education, leaving it to the sole discretion of the superintendent whether to restrict the search to internal candidates or open it up to outsiders. ${ }^{167}$ The only qualified insider was a woman, and she alleged that the superintendent opened the search to outsiders in order to avoid filling the job with a woman. ${ }^{168}$ However, plaintiff stipulated that the individual ultimately hired by the School Board was "unquestionably the most qualified," and the trial court found that sex did not play a part in the Board's hiring decision. ${ }^{169}$ On these facts, with its two levels of decision making, the Sixth Circuit, in an opinion by Judge Kennedy, found no discrimination. "Although [the superintendent] may have acted with a discriminatory motive in opening applications to outside candidates, we cannot find liability for mere use of a process by which the most qualified candidate was ultimately selected in a nondiscriminatory manner." 170

Cesaro, in our view, was wrongly decided. The causal chain between the superintendent's impermissibly motivated act, and the ultimate decision complained of, was unbroken. Had plaintiff not been a woman, the search would not have been opened to outsiders, and she would have obtained the job. Moreover, the decision to open the search to outsiders was a tangible employment action; it was an action

163. Id. at 162.

164. See Long v. Eastfield College, 88 F.3d 300, 306 (5th Cir. 1996) (recognizing that employer generally not liable for impermissibly motivated actions of co-workers).

165. Id. at 160.

166. See supra notes $155-56$ and accompanying text.

167. 953 F.2d 252, 253 (6th Cir. 1992), cert. denied, 506 U.S. 867, 113 S. Ct. 195 (1992).

168. Id. at 254.

169. Id. at 253 .

170. Id. at 256. 
the superintendent's position as superintendent empowered him to take. Thus, the Board should have been held vicariously liable for that impermissibly motivated action. That the Board, as the ultimate decision maker, had no intent to discriminate is irrelevant, as numerous courts have recognized, when the subordinate's tangible employment action plays a causal role in the challenged decision.

\section{Breaking the Causal Chain: Organizational Correction of Biased Evaluations}

Most vertical decision making cases involve a lower level supervisor or manager's recommendation to someone higher in the organizational hierarchy, proposing that he or she take a particular employment action, such as a new hire, a promotion, or a disciplinary action up to and including termination, with respect to a particular employee or applicant. Often, particularly in cases involving disciplinary action, this recommendation is supported by a factual record of some sort, compiled by lower level supervisor or manager, and used by the ultimate decision maker in coming to an eventual decision. Sometimes that decision is made only after the higher-level manager has performed an ostensibly independent investigation. In cases of this sort, where the supervisor's recommendation was tainted by discriminatory motivation, how should a court go about determining whether the causal chain has been broken and the supervisor's bias purged from the decision-making process? In approaching this problem we suggest that insights from the social sciences again prove helpful in formulating a sound doctrinal framework.

First and foremost, courts must take care not to assume from the apparent neutrality of an employer's "independent" investigation that the ultimate decision was not substantially influenced by the supervisor's original report. Many courts examining vertical decision making for the presence or absence of disparate treatment implicitly assume that the ultimate decision maker who receives a recommendation from a lower level supervisor and, following his or her own investigation, ultimately acts on that recommendation, has approached the decision de novo.

Cognitive social psychology teaches that this is not a reasonable assumption. Once a recommendation has been made, it will tend to function as a prior theory-a tentative hypothesis. As such, it can reasonably be expected to influence the ultimate decision maker's judgment in a recommendation-consistent direction, even if he conducts his own investigation. This tendency, which is known as "expectancy confirmation bias," 171 will be magnified where the deficiencies or transgressions

171. The empirical and theoretical literature on expectancy confirmation bias is vast, and we can not begin to reference all the major contributions here. Interested readers are referred to the following leading sources: Charles G. Lord, et al., Biased Assimilation and Attitude Polarization: The Effects of Prior Theories on Subsequently Considered Evidence, 37 J. Personality \& Soc. Psychol. 2098 (1979); Einhorn J. Hillel \& Robin Hogarth, Confidence in Judgment: Persistence of the lllusion of Validity, 85 Psychological Review 395 (1978); Mark Snyder \& William B. Swann Jr., Hypothesis- 
grounding the supervisor's report or recommendation are consistent with a stereotype associated with the target employee's social group. ${ }^{172}$

The key cognitive tendency underlying the expectancy confirmation bias was first illustrated by P. C. Wason in a pair of now classic studies conducted in the 1960 s. $^{173}$ In the earlier of these, Wason asked subjects to imagine a universe consisting of all possible combinations of any three numbers, some but not all of which would conform to a rule known only to the experimenter. Subjects were presented with one such triplet (e.g., 2-4-6) they were told fit the rule. They then were invited to ask the experimenter whether or not other triplets they could think of would fit it as well. Wason discovered that subjects very quickly developed a tentative theory (usually, that rule-conforming combinations would be triplets consisting of consecutive even numbers). But more important to our present inquiry, Wason also found that subjects went about testing that tentative theory by inquiring only about other triplets that would conform to the assumed rule (e.g. 810-12). Once they developed a tentative hypothesis, subjects rarely inquired about number combinations that might disconfirm it. Their stubborn adherence to this confirmatory test strategy significantly delayed their attempt to identify the actual rule (e.g, increasing numbers of whatever kind).

In a second experiment, Wason presented subjects with four cards, reading "E," "K," "4," and "7." While viewing the cards, subjects were asked which ones would have to be turned over to test the theory that "if a card has a vowel on one side, then it has an even number on the other." Because only the " $E$ " and " 7 " cards are capable of disconfirming the theory, they are the normatively appropriate selections. Most subjects, however, (and you might try this on your friends) selected the "E" and " 4 ," cards, those capable of confirming the theory. ${ }^{174}$

Subsequent research has demonstrated quite convincingly that when presented with a claim (i.e., Mary is a poor performer and should be fired), people tend to treat the claim as a tentative hypothesis and proceed to test that hypothesis by searching for evidence that will confirm it. ${ }^{175}$ Moreover, once people have, in this

Testing Processes in Social Interaction, 36 J. Personality \& Soc. Psychol. 1202 (1978).

172. See generally John M. Darley \& Paget H. Gross, A Hypothesis-Confirming Bias in Labeling Effects, 44 J. Personality \& Soc. Psychol. 20 (1983) (demonstrating how expectancy confirmation bias leads to the reinforcement of social stereotypes); John M. Darley \& Rullsel H. Fazio, Expectancy Confirmation Processes Arising in the Social Interaction Sequence, 35 Amer. Psychologist 867 (1980) (same); Mark Snyder, Seek, and Ye Shall Find: - Testing Hypotheses About Other People, 1 Social Cognition: The Ontario Symposium 277 (E.T. Higgins, E. P. Herman, \& Mark P. Zanna, eds., 1981) (review of literature on hypothesis-confirming strategies used in testing hypothesis about stereotyped others).

173. P.C. Wason \& P.N. Johnson-Laird, P. N. The Psychology of Reasoning: Structure and Content (1972); P.C. Wason, On the Failure to Eliminate Hypotheses in a Conceptual Task, 12 Quarterly Rev. of Exp. Psychol. 129 (1960).

174. A useful discussion of the Wason card study can be found in Joshua Klayman \& Young-Won Ha, Confirmation, Disconfirmation, and Information in Hypothesis Testing, in Research in Judgment and Decision Making: Currents, Connections, and Controversies 205, $226 \mathrm{n} .5$ (William M. Goldstein \& Robin M. Hogarth, eds., 1997)

175. See Yaacov Trope \& Erik P. Thompson, Looking for Truth in All the Wrong Places? Asymmetric Search of Individuating Information About Stereotyped Group Members, 73 J. Personality 
way, begun treating a proposition as a tentative theory, they tend to view theoryconfirming information as more probative than theory-disconfirming information, ${ }^{176}$ and they interpret, encode, and retrieve theory-confirming evidence on a preferential basis. ${ }^{177}$

Social expectancy confirmation effects of this type appear strongest in precisely those situations likely to be present in employment discrimination cases, namely, where the decision maker occupies a position of power over the target, ${ }^{178}$ and where the boundary of the hypothesis being tested is relatively extreme. ${ }^{179}$ In short, there is no reasoned basis to assume prima facie that an ostensibly "independent" investigation of a biased (especially a covertly biased) supervisor's allegation or recommendation will correct or "purge" bias introduced earlier in the process. This is particularly true if the supervisor's allegation or recommendation is presented to the ultimate decision maker along with a reasonably well constructed factual account supporting his or her position, ${ }^{180}$ or if the problem involves traits or conduct

\& Soc. Psychol. 229 (1997) (subjects provided with category based expectancies about target people went about gathering information to make an independent judgement by asking questions that, by their nature, were more likely to elicit confirmatory versus disconfirmatory information); Snyder, supra note 172, at 282; See also William B. Swann \& Toni Guiliano, Confirmatory Search Strategies in Social Interaction: How, When, Why, and with What Consequences," 5 J. Soc. \& Clinical Psychol. 511 (1987) (demonstrating that people test their beliefs about others by searching for evidence that confirms those beliefs); Mark Snyder \& Nancy Cantor, Testing Hypotheses About Other People: The Use of Historical Knowledge, 15 J. Experimental Soc. Psychol. 330 (1979) (in a social judgment situation, subjects consistently defined the hypothesis testing task as one of preferentially collecting hypothesisconfirming information).

176. See generally. Snyder, supra note 172, at 295-96; Swann \& Guiliano, supra note 175, at 522 (study demonstrating that simply entertaining a belief raises the perceived diagnosticity of supportive evidence). See also, Lord, et al., supra note 171, at 2098 (people who hold opinions tend to accept confirming information at face value while subjecting disconfirming information to critical scrutiny).

177. Jennifer Crocker, et al., Person Memory and Causal Attribution, 44 J. Personality \& Soc. Psychol. 55 (1983) (discussing attribution and memory processes in relation to expectancy-consistent, expectancy-inconsistent, and expectancy-irrelevant information).

178. Much recent work on expectancy confirmation in social interaction explores the effect of relative power on confirmatory search strategies. These studies consistently find that persons in positions of relative power over their targets are more likely to use confirmatory search strategies than are people with relatively less power over their targets are making judgments about their superiors. See generally Monica J. Harris, et al., Awareness of Power as a Moderator of Expectancy Confirmation: Who's the Boss Around Here, 20 Basic \& Applied Soc. Psychol. 220(1998)(demonstrating the efficacy of perceiver power as a moderator of expectancy confirmation in social judgment); Steven L. Neuberg, Expectancy-Confirmation Processes in Stereotype-Tinged Social Encounters: The Moderating Role of Social Goals, in 7 The Psychology of Prejudice: The Ontario Symposium 103 (Mark P. Zanna \& James M. Olson, eds., 1994); Susan T. Fiske, Controlling Other People: The Impact of Power on Stereotyping, 48 Amer. Psychol. 621 (1993); S.T. Fiske \& S.L. Neuberg, A Continuum of Impression Formation, From Category-Based to Individuating Processes: Infuences of Information and Motivation on Attention and Interpretation, in 23 Advances in Experimental Soc. Psychol. 1 (Mark P. Zanna, ed., 1990).

179. See Yaacov Trope \& Miriam Bassok, Information-Gathering Strategies in HypothesisTesting, 19 J. Experimental Soc. Psychol. 560 (1983) (finding hypothesis-confirming search strategies where the boundary of the expectancy was extreme).

180. See generally, Susan Bisom-Rapp, Bulletproofing the Workplace: Symbol and Substance in Employment Discrimination Law Practice, 26 Fl. S. U. L. Rev. 959 (1999) (demonstrating 
consistent with a stereotype commonly associated with the target employee's social group.

In both single actor and vertical multi-actor contexts, bias injected into the decision making process early in the social judgment sequence can be purged only through affirmative efforts at bias correction. Such an affirmative process would require, among other things, explicitly considering the possibility that bias had influenced the process at its earlier stages, assuring that all available allegation or recommendation-inconsistent facts have been energetically developed and their potential implications thoroughly explored, and subjecting all recommendationconsistent information to rigorous critical scrutiny. Significantly, these are the same types of steps that individual decision makers must take to ensure that unconscious stereotypes do not influence their social judgment and lead them unwittingly to make discriminatory decisions. ${ }^{181}$

In summary, we propose that it should be the combination of two elementsa causal chain ${ }^{182}$ between the plaintiff's protected group status and the challenged decision, and vicarious or direct employer liability for each relevant link in that chain-that results in a viable disparate treatment claim. Without both no claim should exist. But when both are present, neither that the ultimate decision maker had no intent to discriminate, nor even that no conscious intent to discriminate existed at any step of the process, should defeat the plaintiff's case.

\section{Remedial Implications}

Proof of two elements, including a causal link between the plaintiff's group status and the challenged decision, and vicarious employer liability for that causal link, should be sufficient to establish disparate treatment liability. However, a finding of liability does not in all instances entitle a plaintiff to the full panoply of remedies available under employment discrimination laws. For example, under Title VII, a defendant's showing that it would have made the same decision even if it had not taken the protected factor into account serves to limit the remedies to which a plaintiff is entitled. ${ }^{183}$ Under other statutes, such a showing may defeat

employers' ability, through their control of personnel documentation and their access to legal advice, to create a one-sided narrative justifying even an unlawfully biased personnel action).

181. For a thorough discussion of the role of controlled processes in controlling the unconscious effects of stereotypes on social judgment, see Timothy D. Wilson \& Nancy Brekke, Mental Contamination and Mental Correction: Unwanted Influences on Judgments and Evaluations, 116 Psychological Bull. 117 (1994); See also Patricia G. Devine, supra note 126.

182. Whether the causation inquiry demands a showing of "but-for" causation depends upon the ultimate interpretation of Section 703(m) of Title VII and the statutory claims to which its reach ultimately extends. See supra notes 64-68 and accompanying text.

183. 42 U.S.C. $\$ 2000 \mathrm{e}-5$ (g) (2) (B) (Supp. 2000) ("On a claim in which an individual proves a violation under section $703(\mathrm{~m})$ and a respondent demonstrates that the respondent would have taken the same action in the absence of the impermissible motivating factor, the court-. . . . (ii.) shall not award damages or issue an order requiring any admission, reinstatement, hiring, promotion, or payment, described in subparagraph (A))." 
liability entirely. ${ }^{184}$ Moreover, after-acquired evidence of a plaintiff's wrongdoing, while not a basis for avoiding liability, may limit the relief available to the plaintiff. ${ }^{185}$ These principles should apply and in some cases may well limit the relief available in cases involving multiple decision makers, just as they do in a single decision maker setting.

For example, suppose an ultimate decision maker is deciding whether to lay off a particular worker, and in doing so, takes into account disciplinary actions administered by several supervisors. Further suppose that one of those disciplinary actions was racially motivated, but that the others were not. If the employer can prove that the lay off would have occurred had the ultimate decision maker considered only the nondiscriminatory disciplinary actions, then it should be able to limit the remedies for the lay off under Title VII in accordance with Section $706(\mathrm{~g}){ }^{186}$ The impermissibly motivated disciplinary action would have been "a motivating factor" in the layoff decision, but the employer would be entitled to mount a Section 706(g)(2)(B) defense to damages arising from the layoff.

However, the employee should still be entitled to recover damages for the disciplinary action that was caused by race. That discipline would constitute a tangible employment action; thus, vicarious employer liability would exist. ${ }^{187}$ That the action is not an "ultimate" employment action, nor even one carrying immediate economic consequences, should not render it non-actionable under Title VII. ${ }^{188}$ Recovery for the dignitary harms ${ }^{189}$ caused by a racially premised disciplinary action should be recoverable to the extent those damages are available under the particular statute. ${ }^{190}$ But the recovery would be for the harms caused by the disciplinary action, not by the layoff. Moreover in cases in which the employer cannot carry its burden of showing it would have made the same decision had the racially premised disciplinary action not been taken into account, the plaintiff would be able to recover damages for the layoff itself. ${ }^{191}$

184. See supra notes 64-68 and accompanying text.

185. McKennon v. Nashville Banner Publ'g. Co., 513 U.S. 352, 115 S. Ct. 879 (1995).

186. In this circumstance an employer might be able to avoid liability for the lay off entirely under Section 1981. See supra notes 66-68 and accompanying text.

187. See supra notes $154-56$ and accompanying text.

188. See White, supra note 156 , for development of this point. However, there are a number of courts that do require an "ultimate" or "materially adverse" job action in employment discrimination cases. Id. at 1135-47. Were the reasoning of these courts to carry the day, the racially caused discipline would not be actionable, leaving plaintiff without a remedy in situations in which the Section 706(g) defense could be satisfied.

189. See Paul Brest, The Supreme Court 1975 Term. Foreword: In Defense of the Anti Discrimination Principle, 90 Harv. L. Rev. 1 (1976); Weber, supra note 36, at 534 (discussing the noneconomic harms of discrimination).

190. Compensatory and punitive damages have long been available under 42 U.S.C. $\$ 1981(2000)$. See Patterson v. McClean Credit Union, 491 U.S. 164, 182 n.4, 109 S. Ct. 2363, 2375 n.4 (1989). They are now available under Title VII as well, 42 U.S.C. $\$ 1981$ (a) (2000). Vicarious employer liability for punitive damages must satisfy the heightened standard set forth in Kolstad v. American Dental Ass' $n$, 527 U.S. 526, 119 S. Ct. 2118 (1999).

191. See, e.g., Simpson v. Diversitech Gen. Inc., 945 F.2d 156 (6th Cir. 1991); Barbano v. Madison County, 922 F.2d 139 (2d Cir. 1990). 
Now consider a variation, one that demonstrates whether actors higher in the chain of authority might remove the "taint" of a tangible employment action caused by race or sex. Suppose a supervisor imposes a three day suspension on plaintiff upon learning that plaintiff had stolen company product. However, the supervisor is aware of similar theft by the plaintiff's co-workers, all of whom are white, and has not disciplined those workers. Instead he has chosen to discipline the plaintiff, who is black, because of his race. The disciplinary action triggers an investigation into employee theft, and the Director of Human Resources, because of the seriousness of thefts, decides to fire all employees who have been caught stealing, including the plaintiff. What remedy should lie?

Certainly, there is a causal link between the plaintiff's race and his termination. But for the plaintiff's race, he would not have been disciplined, there would have been no investigation into employee theft, and no termination. Moreover, the disciplinary act, a three day suspension, is a tangible employment action for which the employer is vicariously liable. Is the employer then precluded from firing the plaintiff because of this "taint"?

McKennon v. Nashville Banner Publishing Co. teaches that the answer is no. There, the plaintiff removed company documents without her employer's permission, a transgression that was uncovered during her deposition in connection with her age discrimination case. The employer argued that this wrongdoing relieved it of any liability for age discrimination, a proposition unanimously rejected by the Supreme Court. If the employee was fired because of her age, she was entitled to a remedy for that statutory violation. However, the Court went on to hold that the employee's wrongdoing. could be considered in fashioning a remedy. Balancing protection of the employee's statutory right to be free from age discrimination against the employer's managerial prerogatives in running its business, the Court concluded that the wrongdoing could serve to preclude reinstatement and to cut off back pay liability as of the date of the employer's discovery of the employee's wrongdoing:

Once an employer learns about employee wrongdoing that would lead to a legitimate discharge, we cannot require the employer to ignore the information, even if it is acquired during the course of discovery in a suit against the employer and even if the information might have gone undiscovered absent the suit. ${ }^{192}$

These principles should govern the above-described hypothetical. Although race discrimination led to the discovery of the employee's wrongdoing, the employer would not be required to ignore that wrongdoing. If the employer can show that it fired the plaintiff because of his theft, even if it learned of that theft through a racially-premised disciplinary action, the termination itself would be permissible.

Again, however, this result does not leave the plaintiff without a remedy. The plaintiff still should be able to recover for the dignitary harms caused by the

192. 513 U.S. $352,362,115$ S. Ct. 879,886 (1995). 
supervisor's race-based disciplinary action. ${ }^{193}$ Such a result serves the compensatory and deterrence goals of the statute while respecting the employer's legitimate business interests. Accordingly, while liability will exist in a vertical decision making context when both the requisite degree of causation and vicarious employer liability exist, the remedies available for that discrimination may be limited by actions taken further up in the organizational hierarchy.

\section{HORIZONTAL DECISION MAKING}

Sometimes, employment decisions are made by a committee or other group of individuals. In such situations, some persons within the group may act out of hostile animus or prejudice, or may for some other reason deliberately factor race, sex, age, or national origin into their decision making calculus. Others may unconsciously act for those reasons. Still others may act for reasons having no causal relationship to race, sex or age. In these horizontal decision making situations, when may a decision properly be considered to have resulted from "intentional discrimination"? Again, we suggest, a disparate treatment claim should lie when the plaintiff's race, sex or age caused the decision to occur and where the key actions in the causal chain can be attributed to the employer.

As others have observed, asking whether a group consciously intended to discriminate makes little sense. ${ }^{194}$ As Professors Lee \& Bhagwat, who advocate a purely causation based approach to intent in constitutional cases, have noted:

In the collective context, the concept of conscious intent is not merely difficult to prove, it is meaningless. Groups do not have mental states, and while individual members of groups might be shown to possess particular mental states, there is no evident reason to attribute the motive of any particular individual to the group as a whole. ${ }^{195}$

To apply the concept of conscious discriminatory intent literally in the group decision making context, one would have to determine the conscious motives of each group member. One could then tally the results. Only if a majority consciously took race, sex or age into account would a claim exist. But that approach is at odds with our understanding of how groups work. ${ }^{196}$ Within any group, some persons are more influential than others. A strong personality, consciously but secretly motivated by animus, may be able to influence a decision even when a majority of the group's members had no awareness that race, sex or age was playing a role. ${ }^{197}$

193. See supra notes $187-91$ and accompanying text.

194. Professor Sullivan points out, "The collegial body obviously does not 'think' at all; its human members have whatever motivations may be relevant for Title VII purposes." Sullivan, supra note 7 , at 1139 n.117.

195. Lee \& Bhagwat, supra note 22, at 154. See Strauss, supra note 22 (viewing causation, not conscious motive, as the proper way of understanding of intent in the Court's constitutional cases).

196. See Sullivan, supra note 7, at 1154 .

197. Id. at 1139 n.117 ( noting that when "opinion leaders" act from a prohibited motive it may 
Moreover, at least in the context of legislative decision making, the Supreme Court has recognized that a search for conscious intent on the part of individual decision makers would be impracticable, if not impossible. ${ }^{198}$ Plumbing the psyche of each person who voted for a particular measure, constitutional concerns aside, is unlikely to be productive. It is also unnecessary. If we examine the legislative decision making cases closely, we see that the Court is searching, much as it does in individual disparate treatment cases under Title VII, for evidence that group status was a motivating factor in a legislative decision. ${ }^{199}$

Indeed, in Hunter $v$. Underwood, ${ }^{200}$ in which the Court was required to ascertain the intent of the entire 1901 Alabama Constitutional Convention, Justice Rehnquist, writing for a unanimous Court, articulated a standard virtually identical to that adopted in Price Waterhouse v. Hopkins. Stated Justice Rehnquist: "Once racial discrimination is shown to have been a 'substantial' or 'motivating' factor behind the enactment of the law, the burden shifts to the law's defenders to demonstrate that the law would have been enacted without this factor."201

Other decisions provide guidance regarding the types of evidence that can be used in connection with this essentially causal inquiry. For example, in Village of Arlington Heights v. Metropolitan Housing Development Corp. ${ }^{202}$ the Court specified various types of evidence that could be used to demonstrate that a legislative body acted with a discriminatory purpose. These types of evidence include the decision's impact on a protected group, the historical background against which the decision was made, the events leading up to the decision, the occurrence of substantive or procedural irregularities, and statements made by members of the decision-making body. If we combine first, the Court's acknowledgment in Hunter and $O^{\prime} B r i e n$ that a search for each individual legislator's intention is impracticable, second, the simple fact that groups don't "think," and third, the motivating factor/but-for causation analysis set out in Hunter, we are led inexorably to conclude that the critical inquiry in the legislative decision making context cannot possibly center on conscious discriminatory intent, literally

be fair to find the decision wrongfully motivated, even when the "followers" are unaware of the prohibited motive of the leaders); Elena Kagan, Private Speech. Public Purpose: The Role of Governmental Motive in First Amendment Doctrine, 63 U. Chi. L. Rev. 413, 440 n.80 (1996) (describing the disproportionate influence some legislators have and the difficulties that poses for determining motive).

198. See, Hunter v. Underwood, 471 U.S. 222, 228, 105 S. Ct. 1916, 1920 (1985) (stating, "[p]roving the motivation behind official action is often a problematic undertaking."). See also United States v. O'Brien, 391 U.S. $367,383,88$ S. Ct. 1673, 1682 (1968) (stating that "inquiries into congressional motives or purposes are a hazardous matter."). See Kagan, supra note 197, at 438-42 (discussing the difficulties of determining illicit motive in the legislative context; and characterizing $O^{\prime} B r i e n$ as standing for the proposition that direct inquiry into motives for restricting speech very rarely will prove productive.").

199. See Kagan, supra note 197, at 442-43; See also Brest, supra note 189, at 120 (suggesting that the search for motive in multiple decision maker cases should be treated the same as when a single decision maker is involved).

200. 471 U.S. 222, 105 S. Ct. 1916 (1985).

201. 471 U.S. at $228,105 \mathrm{~S}$. Ct. at 1920.

202. 429 U.S. 252,97 S. Ct. 555 (1977). 
understood.

As Professor Selmi asserts, Arlington Heights, with its focus on circumstantial evidence, supports this approach. Some sort of collective conscious bias can not logically be viewed as prerequisite to a finding of intentional discrimination in a group decision making context. As Selmi notes: "Significantly, none of the factors listed in Arlington Heights requires proof of knowledge or awareness on the part of the actor, but rather all are circumstantial facts that give rise to an inference of discrimination."203 The question of discriminatory intent, argues Professor Selmi, does not revolve around a search for a particular conscious state of mind. Rather, it entails a search for causation. ${ }^{204}$

In a similar vein, Professor Kagan, who asserts that the Court's First Amendment doctrine in fact is aimed at determining whether a challenged law is the product of an improper government motive, contends that the search for intent or motive in these legislative decision making cases is best understood as an issue of but-for causation. ${ }^{205}$ Rather than searching for the state of mind of any particular person, or even of the decision making body itself, a court is, and properly should be, looking for the influence, if any, of a particular factor in the decision-making process. $^{206}$ Moreover, Professor Kagan suggests, a court makes that determination through an examination of circumstantial evidence indicating that the protected factor caused a particular decision to be made. ${ }^{207}$

This approach may readily be carried over into the statutory employment discrimination context. ${ }^{208}$ Employment decisions, like legislative acts, often are the product of group decision making. A search for the conscious bias or intent of group members is as unproductive and meaningless in the employment context as it is in the legislative context. Instead, the record should be considered as a whole to determine whether plaintiff's group status played a role, or was the but-for cause, of the decision at issue. ${ }^{209}$

The academic setting, which has produced its share of employment discrimination cases, provides a useful model for examining horizontal group decision making. ${ }^{210}$ In Curley v. St. John's University, ${ }^{211}$ for example, the plaintiff contended he had been denied the opportunity to teach graduate courses because of

203. Selmi, supra note 22, at 304.

204. Id. at 289. Professor Selmi criticizes the Court, however, as too often unwilling to infer discrimination from circumstantial evidence. Id. at 334-35.

205. Kagan, supra note 197, at 439.

206. Id.

207. Id. at 442-43. Professor Kagan argues the rules the Court has developed for analyzing First Amendment claims, much like the presumptions and burdens of proof developed in the employment arena, are aimed at "flush[ing] out bad motives." Id. at 443.

208. Selmi, supra note 22 , at 301-02.

209. See supra notes 64-68 and accompanying text for a discussion of the different causation models applicable in the employment discrimination context.

210. West, supra note 6, at 125-26 (noting that academic settings usually involve decision making by multiple committees, and that such a system "does not easily fit under the Title VII theory or structure").

211. 19 F. Supp.2d 181 (S.D.N.Y. 1998). 
his age. The recommendation that plaintiff be restricted to undergraduate teaching had been made by a Peer Review Committee, which recommendation the Dean had accepted. ${ }^{212}$ Pointing to discriminatory statements made by one of the committee members, ${ }^{213}$ plaintiff alleged that the committee's recommendation was motivated at least in part by age, and he sought to hold the university liable under the ADEA. ${ }^{214}$ The university moved for summary judgment, arguing that the comments of a faculty peer were an insufficient basis for imputing wrongful motive to the university when the dean made the "final decision." 15 The trial court denied the university's motion. That other group members, and the Dean, may have acted for reasons unrelated to age did not of itself relieve the university of liability. As the court noted: "A plaintiff need not prove every one of the decision-makers biased in order to argue that the discriminatory motives of some of the decision-makers rendered the decision discriminatory."216 If plaintiff could show that his age was a motivating factor in the decision to deny him graduate courses, he would be entitled to a verdict in his favor.

But providing such proof has been difficult for plaintiffs in settings where collective decision making is the rule. ${ }^{217}$ In Fisher v. Vassar College, for example, the court, while recognizing that a group decision making process should not insulate a university from liability, found insufficient evidence that plaintiff's sex had motivated her denial of tenure. ${ }^{218}$ The court reversed a verdict in favor of the plaintiff despite evidence calling into question the nondiscriminatory reasons articulated by the university. "Because there are numerous participants in the decision-making process, each potentially.having individual reasons for rejecting a plaintiff, there is a greater likelihood that some of those reasons will differ from the reason officially given by the institution," said the court in discounting the plaintiff's evidence. ${ }^{219}$ Thus, despite its recognition that an employer should not be able to insulate its discriminatory decisions by using a group decision making process, the Fisher court in fact made it more difficult for plaintiffs to prevail in

212. Id. at 184 .

213. Plaintiff alleged that one of the committee members, Dr. Giuseppe, asked him why he would want to stay around after he had turned 60 and commented that "when you hit the big 60 you are over the hill." Id. at 185.

214. Id. at 183.

215. Id. at 183 .

216. Id. at 192.

217. Namenwirth v. Board of Regents of U. of Wis. System, 769 F.2d 1235 (7th Cir. 1985) (discussing the difficulty of eliminating discrimination in tenure cases). In Namenwirth, despite the fact that the plaintiff was the first woman hired in a tenure track position in her department in thirty-five years and the first person denied tenure by her department, the court found insufficient evidence that sex motivated the decision. See West, supra note 6, at 127 (describing the difficulties female plaintiffs in academic settings have faced, in large part because of the committee structure of decision making, and stating: "These academic cases indicate how difficult it is for a plaintiff to attribute the prejudice shown by the remarks of one member of a decision-making committee to the decision of the committee as a whole, or to the eventual adverse action against the plaintiff.").

218. 114 F.3d 1332 (2d Cir. 1997).

219. Id. at 1338 . 
such cases.

The search for discriminatory intent in these group decision making cases, however, should proceed as it would in cases involving a single decision maker or a vertical decision making process. The court should ask whether there is a causal chain between the protected characteristic and the challenged decision and whether the events that comprise that chain are attributable to the employer.

The plaintiff's prima facie case, treatment of those similarly situated, procedural irregularities, and evidence calling into question the defendant's proffered justification for its decision, all may usefully be analyzed in determining whether the protected characteristic played a causal role. ${ }^{220}$ Discriminatory statements by one or more group members, whether or not those statements were made during the group's deliberative process, also provide circumstantial evidence that the plaintiff's race, sex, national origin or age was a motivating factor in the group's decision.

However, unless courts bring to the task of drawing inferences from circumstantial evidence a realistic understanding of group decision making dynamics, no legal standard, whether framed in terms of causation or in terms of discriminatory intent, will yield sound results. Unfortunately, this sort of realistic understanding is too often absent from decisions involving horizontal decision making groups.

For example, it would be a mistake for courts to assume that members of a decision making group will object to or block decisions they consider wrongfully motivated where those decisions are favored by powerful group members. Although a thorough review of the literature on compliance with authority is beyond the scope of this project, numerous psychological studies have confirmed people's tendency, given certain conditions, to comply with authority and to engage in conduct that they would otherwise consider morally wrong. Perhaps the most famous (or infamous) are the Milgram experiments conducted in the 1960 s. $^{221}$ In that study, subjects were willing to administer what they believed to be painful or even deadly shocks to other persons when directed to do so by the experimenter. ${ }^{222}$ Milgram's study, among other things, vividly illustrates how difficult it is for people to break out of highly scripted interactions dominated by a person in apparent authority, even when they are being called upon to engage in conduct they would surely find abhorrent.

While not as dramatic as the Milgram experiments, numerous other studies aptly illustrate the fallacy of assuming that individual members of a decision making group will buck group norms and speak their minds. For example, during the

220. See Simon, supra note 22, at 1097-1101 (advising courts to look for same forms of circumstantial evidence of group's motives as would be considered in cases involving individual decision maker).

221. Stanley Milgram, Obedience to Authority (1974).

222. As the shock levels and the learner's protests increased, subjects began questioning the experimenter. However, the experimenter, no matter what the subject's question or complaint, was instructed to give one of a small, set number of stock responses, including "Please continue," "The experiment requires that you continue," "It is absolutely essential that you continue," or "You have no other choice, you must go on." The results were stunning. Sixty-two percent of subjects administered shocks all the way up to 450 volts, even after the "learner" had screamed in pain one final time and fallen silent 120 volts earlier. Id. 
1950s, Solomon Asch conducted a study demonstrating that people's reports about their own visual perceptions (if not the perceptions themselves) can be profoundly influenced by the behavior of other members in an ad hoc group. ${ }^{223}$ Asch's group conformity study extended an earlier finding by Muzafir Sharif that group norms could influence not only how people describe their perceptions, but also what people in fact perceive. ${ }^{224}$

Both Asch's and Sherif's studies were performed using ad hoc groups, in which group members had no real power to determine subjects' future outcomes in any way. Even in these situations, people have a strong tendency to respond to subtle signals embedded in social interactions, and to bring their behavior into conformity with the norms those signals suggest are operating within the group. As this and subsequent work in organizational behavior demonstrates, group norms can powerfully shape members' perceptions of objective and subjective phenomena, their notions of acceptable procedures and patterns of discourse, their prioritization of differing goals, and the interpretive "frames" they bring to the decision making process. $^{225}$

It is reasonable to assume that both compliance with authority and group conformity effects operate even more powerfully in the workplace, where being perceived as a "team player" is often essential to one's economic survival. Within organizations, working groups rapidly develop a set of norms, which shape the conditions of interaction between group members and powerfully influence the direction of group decision making. ${ }^{226}$ Group norm compliance effects interact with

223. S.E. Asch, Effects of Group Pressure Upon the Modification and Distortion on Judgments, in Groups, Leadership, and Men: Research in Human Relations 177 (Harold Guetzkow, ed., 1951). Asch asked subjects to participate in a study, ostensibly with six other subjects, of visual perception. The other six subjects were in fact confederates working with the experimenter. Subjects were shown a series of two posters. In each case, one poster had a single line on it, while the other poster bore three lines of varying lengths. The single line on the one poster was always quite obviously the same size as one of the three lines on the other.

The "subjects," first five of the confederates and then the real subject, were asked to state which of the lines on a three-line poster was the same size as the line on the corresponding one-line poster. Sometimes, they gave the obviously correct answer, but, as the experiment progressed, all six confederates began giving the wrong answers, always with the same ease and assurance as they had while giving correct answers.

In the face of five incorrect answers, 80 percent of subjects went along with the five confederates in at least one trial. In the aggregate, subjects went along with the group and gave incorrect responses approximately 30 percent of the time, despite the obviousness of the correct response. For a subsequent description and explication of these studies, see Solomon E. Asch, Opinions and Social Pressure, Sci. Am., Nov. 1955, at 31-35.

224. Sherif's "autokinetic effect" studies are described in Muzafir Sherif, The Psychology of Social Norms 89-112 (1936).

225. See Clayton P. Alderfer, An Intergroup Perspective on Group Dynamics, in Classic Readings in Organizational Behavior, 140, 142 (J. Steven Ott, ed., 1996) (discussing effect of group norms on cognitive formations).

226. See generally, Robert R. Blake, et al., Foundations and Dynamics of Intergroup Behavior, in Classic Readings in Organizational Behavior, 121, 122-23 (J. Steven Ott, ed., 1996) (discussing emergence of group norms in organizational subgroups). 
emerging patterns of authority and influence in a working group. ${ }^{227}$ As these patterns develop, higher status brings with it a right to dissent or diverge from group norms, whereas lower status members, even if their own views diverge from an apparent group consensus, are more likely to engage in what is known as "expedient conformity."228

If courts are to draw reasonable inferences from circumstantial evidence in group decision making cases, they must become far more sophisticated about the dynamics of group process. Such sophistication would prevent courts from assuming, for example, that if minority group members are included within the decision making group, their presence is an assurance that discrimination is unlikely to have occurred. ${ }^{229}$ At the same time, courts must build a doctrinal framework capable of guiding the factual inquiry in a sensible way, which, combined with accurate models of group decision process, will yield sound outcomes in specific cases. In our view, the first step in building such a framework is to acknowledge that in these and other disparate treatment cases, the court's inquiry should center on two questions: is there an unbroken causal chain between the plaintiff's group status and the challenged decision, and are the actions that comprise that chain attributable to the employer?

In determining whether a causal link exists, the Reeves court has recognized that evidence discrediting the reason articulated by an employer can indicate that an unlawful motive was operating. ${ }^{230}$ Such evidence should not be discounted, as the Fisher court did, simply because the decision is the product of group decision making. Rather than attempting to ascertain the motives of each group member, the court instead should assess the circumstantial evidence as a whole to determine whether there is sufficient evidence that the plaintiff's race, sex, or other protected characteristic actuated the decision. ${ }^{231}$ A prima facie case, coupled with evidence calling into question the truthfulness of the proffered reason, generally should be sufficient to support a verdict in the plaintiff's favor, whatever form the decision making process assumed. ${ }^{232}$

227. See generally, Robert R. Blake, et al., Foundations and Dynamics of Intergroup Behavior, in Classic Readings in Organizational Behavior, supra note 225, at 122-33 (discussing the development of status and power allocation in intra-organizational subgroups).

228. James L. Bowditch \& Anthony Buono, A Primer on Organizational Behavior 153 (defining "expedient conformity" as a situation in which a group member expresses attitudes or engages in behaviors that conform to group norms despite holding private beliefs that are at odds with group sentiment).

229. See, e.g., St. Mary's Honor Center v. Hicks, 509 U.S. 502, 508 n.2, 113 S. Ct. 2742, 2748 $\mathrm{n.2}$ (1993) (describing district court's finding that race unlikely to have motivated decision because two members of the decision-making group were black.).

230. 530 U.S. 133, 120 S. Ct. 2097, 2108 (2000).

231. For example, in Namenwirth v. Board of Regents of U. of Wis. System, 769 F.2d 1235 (7th Cir. 1985), the dissenting judge chastised the majority for appearing to insist on conscious bias on the part of a university committee in a tenure denial case. Instead, the dissent asserted, the court should have examined all of the circumstances, including the fact that the plaintiff was the first woman hired in her tenure track position in her department, and the first person denied tenure, in $\mathbf{3 5}$ years, in deciding whether plaintiff's sex was a likely explanation for the challenged decision.

232. Reeves, 530 U.S. at 154, 120 S. Ct. at 2112 (Ginsberg, J., concurring). See McGinley, supra 
In many group decision making situations, however, as exemplified by those arising in Curley and Fisher, the group may be composed of co-workers, not supervisors. Generally, an employer is not vicariously liable for the actions of an employee's coworkers, as they are not agents of the employer. ${ }^{233}$ In these group decision making cases, even though a causal link exists, may an employer avoid liability when no supervisory employee has acted because of a protected characteristic?

The answer, again looking to the reasoning of Ellerth, is no. Although group members may be peers or co-workers of the plaintiff, and generally would not be considered agents of the employer, ${ }^{234}$ when the employer has delegated decision making authority to the peer group, they become agents for purposes of the particular decision. ${ }^{235}$ When the employer has empowered the co-workers to take a tangible employment action, the employer is vicariously liable for the action, because absent that delegation of authority to the group, the injury could not have been inflicted by the group. "[O]nly a supervisor, or other person acting with the authority of the company, can cause this sort of injury." 236 As noted by the trial court in Curley v. St. John's University, even if group members are peers, "they are peers with power to affect the terms and conditions of Dr. Curley's employment in material adverse ways."237 But for the university's decision to place the power to make the decisions in the hands of a university committee, the group would have had no means to deprive Dr. Curley of his graduate teaching status. Thus, just as in a single or vertical decision maker setting, the employer will be vicariously liable for actions it has empowered its agents to take..$^{238}$

\section{CONCLUSION}

The search for a discriminatory motive in disparate treatment cases often is envisioned as an attempt to determine whether a supervisor, despite his denials,

note 22, at 485 (advocating advising juries that a prima facie case, coupled with proof of prextext, "can raise an inference that the employer, in evaluating the employee, was either consciously or unconsciously influenced by the employee's race, gender or national origin.").

233. The Ellerth Court rejected the argument that the workplace setting, which provides workers with proximity to each other, is itself a sufficient basis for imposing vicarious liability on the employer for workplace wrongs, whether committed by co-workers or supervisors. "The aided in the agency relation standard, therefore, requires the existence of something more than the employment relation itself." Burlington Indust., Inc. v. Ellerth, 524 U.S. 742, 760, 118 S. Ct. 2257, 2268 (1998).

234. Id.

235. It is the delegation of this authority, the empowerment by the company to inflict this sort of harm, that renders the employer vicariously liable for the agent's action, under the "aided in the agency relation" standard. Id. at $763,118 \mathrm{~S}$. Ct. at 2269.

236. Id. at $762,118 \mathrm{~S}$. Ct. at 2269 (emphasis added).

237. 19 F. Supp.2d 181, 192 (S.D.N.Y. 1998). The Court considered the decision to preclude Dr. Curley from teaching graduate classes to be a "materially adverse" action. Whether a tangible employment action must be materially adverse is debatable. See White, supra note 156, at 1154-60. However, a materially adverse action undeniably is a tangible employment action within the meaning of Ellerth. 524 U.S. at 761,118 S. Ct. at 2268 .

238. "If an employer entrusts personnel decisions to persons who act on the basis of impermissible motives, the employer is responsible for the resulting act of discrimination." Fisher v. Vassar College, 114 F.3d 1332, 1371(2d Cir. 1997) (Newman, J., dissenting). 
consciously acted out of bias, animus or on the basis of "inaccurate and stigmatizing stereotypes" in making an employment decision. Framing the search for discriminatory motive is this way, however, cannot prove fully effective in eliminating discrimination, as individuals may be unaware of their own biases or the influences those biases have had on their own decision making.

The reality of decision making in the employment area, moreover, is that multiple individuals are often involved in making employment decisions affecting an employee. Just as an individual may be unaware of his own biases, so too, the ultimate decision maker or members of a decision making group may be unaware that others involved in the decision making process have based their decisions, in whole or in part, on an employee's race, sex or other protected characteristic. Importantly, that unawareness generally has not been considered a sufficient basis for depriving a plaintiff of her discrimination claim in these multiple actor cases. This is so because courts have recognized that impermissible considerations of protected group status in one part of the decision-making chain may cause a job action to occur, even though other participants were unaware that protected status had played a role in the process.

This causation based inquiry in multiple actor cases usefully informs how discriminatory intent or motive is best understood in any decision making context. In cases involving a single decision maker, as in those involving multiple decision makers, the question should not be whether a conscious use of race, sex or age has been injected into the decision making process. Instead, it should simply be whether the employee's race, sex, or other protected characteristic has played a causal role in the decision making process. If so, then a disparate treatment claim should exist, so long as that causal link may be attributed to the employer, directly or vicariously. Understanding the interplay and importance of both causation and vicarious liability provides a meaningful way of thinking about the intent requirement in disparate treatment claims, whether in the individual or multiple actor context. 